\title{
Extensive $\mathrm{CO}_{2}$ degassing in the upper mantle beneath oceanic basaltic volcanoes: First insights from Piton de la Fournaise volcano (La Réunion Island)
}

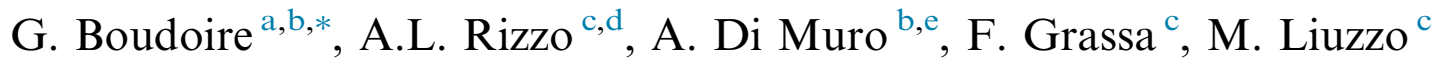 \\ ${ }^{a}$ Laboratoire Géosciences Réunion, Université de La Réunion, Institut de Physique du Globe de Paris (IPGP), Sorbonne Paris-Cité, UMR \\ 7154 CNRS, F-97715 Saint-Denis, France \\ ${ }^{\mathrm{b}}$ Observatoire Volcanologique du Piton de la Fournaise (OVPF), Institut de Physique du Globe de Paris (IPGP), Sorbonne Paris-Cité, \\ UMR 7154 CNRS, Université Paris Diderot, Bourg Murat, France \\ ${ }^{\mathrm{c}}$ Istituto Nazionale di Geofisica e Vulcanologia, Sezione di Palermo, Via Ugo La Malfa 153, 90146 Palermo, Italy \\ ${ }^{\mathrm{d}}$ Dipartimento di Fisica e Scienze della Terra, Università degli Studi di Ferrara, Italy \\ ${ }^{\mathrm{e}}$ Institut de Physique du Globe de Paris (IPGP), Sorbonne Paris-Cité, UMR 7154 CNRS, Université Paris Diderot, F-75005 Paris, France
}

\begin{abstract}
In spite of its major role on the atmospheric volatile budget, climate, and tracking magmatic transfers, mantle $\left(\mathrm{CO}_{2}\right)$ degassing below volcanoes is still poorly understood. Most of the studies on this scientific topic lack constraint on the $\mathrm{CO}_{2}$ concentration of primary melts, the depth at which it starts degassing, and the extent of this process in the mantle. In this study of Piton de la Fournaise (PdF) volcano, we couple geochemistry of low solubility gases $\left(\mathrm{He}, \mathrm{Ar}, \mathrm{CO}_{2}, \delta^{13} \mathrm{C}\right)$ in fluid inclusions (FIs) and petro-chemistry of magmatic inclusions on a set of olivine and clinopyroxene crystals from basalts and ultramafic enclaves.

We constrain basaltic melt degassing at PdF over a large pressure range (from $4 \mathrm{GPa}$ up to the surface). Based on $\mathrm{CO}_{2}-\mathrm{He}-$ Ar systematics, we infer that extensive degassing occurs already in the upper mantle (4-1 GPa) and it is favored by multiple steps of magma ponding and differentiation up to the mantle-crust underplating depth $(0.4 \mathrm{GPa})$. Thus, we calculate that basaltic melts injected at crustal depth $(<0.4 \mathrm{GPa})$ have already exsolved $\sim 94 \pm 5 \mathrm{wt} \%$ of their primary $\mathrm{CO}_{2}$ content in accordance with (1) the evolved and degassed signature of erupted lavas and (2) the weakness of inter-eruptive gas emissions in the active area bearing low-temperature vapor-dominated fumaroles. Our results at PdF strongly contrast with previous findings on other ocean island volcanoes having a higher magma production rate and faster magma ascent, like Kilauea (Hawaii), whose basalts experience only limited extent of differentiation and degassing. We propose that extensive degassing already in the upper mantle can be a common process for many volcanoes of the Earth and is tightly dependent on the dynamics of magma ascent and differentiation across multiple ponding zones.

Based on the modeling developed in this study, we propose a new estimation of the $\mathrm{CO}_{2}$ content (up to $3.5 \pm 1.4 \mathrm{wt} \%$ ) in primary basaltic melts at PdF leading to a carbon content in the mantle source of $716 \pm 525 \mathrm{ppm}$. This new estimation is considerably higher than the few previous calculations performed for Ocean Island Basalts (OIB) systems. Another implication of this work involves the possible bias between the $\delta^{13} \mathrm{C}$ measured in volcanic gas emissions $(<-6 \%)$ and that of primary vapour phase $\left(-0.5 \pm 0.5 \%\right.$ ) constrained in this work. This bias would confirm the early step of extensive $\mathrm{CO}_{2}$ degassing within the upper mantle and could represent an alternative for the hypotheses of carbon recycling or mantle heterogeneity in support of the low $\delta^{13} \mathrm{C}$ signature of some mantle reservoirs. This study bears significant implications on the global budget of volcanic volatile emissions, chiefly regarding the contribution of past and future emissions of volcanic $\mathrm{CO}_{2}$ to climate dynamics, and on volcanic gas monitoring.
\end{abstract}

\footnotetext{
* Corresponding author at: Observatoire Volcanologique du Piton de la Fournaise (OVPF/IPGP), Impasse de l'Observatoire, Bourg Murat 97418, France.

E-mail address: guillaume.boudoire@gmail.com (G. Boudoire).
} 


\section{INTRODUCTION}

Magmatic degassing is an exciting field of investigation to develop reliable models for forecasting volcanic activity (Tazieff and Tonani, 1963; Le Guern et al., 1982; Allard et al., 1991; Scarpa, 2001; Aiuppa and Federico, 2004; Liuzzo et al., 2013; Rizzo et al., 2006, 2009, 2015). Among major volatiles emitted from volcanoes, $\mathrm{CO}_{2}$ has a low solubility in melts and is released at great depth strongly contributing to the deep carbon cycle (Marty and Jambon, 1987; Dasgupta and Hirschmann, 2010; Marty et al., 2013; Manning, 2014; Lee et al., 2016; Mason et al., 2017 and references therein). $\mathrm{CO}_{2}$ is thus the major nonaqueous constituent of magmatic gases and the principal carrier for other trace volatiles like noble gases (Barry et al., 2014; Gilfillan et al., 2014). Consequently, it is extensively used to constrain deep degassing when coupled to noble gases (e.g., ${ }^{4} \mathrm{He} / \mathrm{CO}_{2}, \mathrm{CO}_{2} / \mathrm{Ar},{ }^{4} \mathrm{He} /{ }^{40} \mathrm{Ar}^{*}$ ) due to the low but distinct solubility between these species (Jambon et al., 1986; Burnard, 2004; Burnard et al., 2003, 2014; Aubaud et al., 2004; Paonita and Martelli, 2007; Paonita et al., 2012). The isotope composition of carbon $\left(\delta^{13} \mathrm{C}\right)$ of $\mathrm{CO}_{2}$ is also an important tracer of magmatic degassing, because it fractionates during this process moving towards lower values (Javoy et al., 1978; Mattey, 1991; Trull et al., 1993; Shaw et al., 2004).

Even if the volcanic contribution to the total $\mathrm{CO}_{2}$ budget in the Earth atmosphere is minor with respect to anthropogenic emissions, it strongly influences the climate dynamics with disastrous consequences for the ecosystems (Le Guern et al., 1975; Allard et al., 1991; Oppenheimer et al., 2011; Burton et al., 2013; Carn et al., 2017). A critical issue to constrain deep $\mathrm{CO}_{2}$ degassing below volcanoes and evaluate the primary magmatic volatile budget is that most of the studies: (1) focus on late-stage products (as residual glasses or free gases), which are more prone to be affected by secondary effects (Marty et al., 1992; Caracausi et al., 2003; Capasso et al., 2005; Aubaud et al., 2004, 2006); (2) deal with Mid Ocean Ridge Basalts (MORB) systems and only a few data concern Ocean Island Basalts (OIB) systems (see Barry et al. (2014) for a complete review); (3) lack of constraints on pressures of exsolution, most of barometric data being estimated from experimental and modeling studies on noble gases (Caracausi et al., 2003; Sarda and Guillot, 2005; Iacono-Marziano et al., 2010; Paonita et al., 2012).

In this study, we focus on a set of crystals (olivine, clinopyroxene) from various products (pyroclasts and ultramafic enclaves) and eruptive sites (central and peripheral areas) of the Piton de la Fournaise shield volcano (La Réunion Island), which is considered as a reference example of basaltic activity in an OIB geodynamic setting (Courtillot et al., 2003). The eruptive products were selected with the aim at tracking a broad range of pressure, from the upper mantle to the crustal volcano plumbing system, and thus to constrain the extent of magma degassing and evolution during its ascent. We adopt an approach that couples gas geochemistry ( $\mathrm{He}, \mathrm{Ar}, \mathrm{CO}_{2}, \delta^{13} \mathrm{C}$ ) of fluids inclusions and petro-chemistry of pyroclasts and enclaves (crystal composition, fluid inclusion composition and barometry) in order to (1) constrain the volatile content of primary basaltic melts and (2) estimate the extent of magmatic evolution and degassing below the volcano as a function of depth. The PdF volcano was targeted due to (1) its intense eruptive activity (one eruption each nine months since 1985; Roult et al., 2012) contrasting with limited gas emissions during inter-eruptive periods (see Di Muro et al. (2016) for a review), (2) the homogeneity of the mantle source limiting the initial variability in composition (noble gases, $\mathrm{CO}_{2}$ and $\delta^{13} \mathrm{C}$, Graham et al., 1990; Füri et al., 2011; Schiano et al., 2012; Vlastelic and Pietruzska, 2016), and (3) similarities between its plumbing system and those inferred for many other ocean basaltic volcanoes (Michon et al., 2015). These features make this volcano an interesting natural laboratory to study deep magma transfer and degassing from mantle to crustal level (Liuzzo et al., 2015; Di Muro et al., 2016; Boudoire et al., 2017a,b).

\section{GEOLOGICAL SETTING}

Located in the Indian Ocean, La Reunion Island (latitude: $-21^{\circ}$; longitude: $56^{\circ}$ ) is the youngest volcanic island of the chain attributed to the activity of hot spot, which produced the Deccan flood basalt province in India 65 Myrs ago (Mahoney et al., 2002). The volcanic edifice rises $7 \mathrm{~km}$-high on the ocean floor, which consists of a Upper Cretaceous-to Paleocene oceanic crust. The Moho is located at $10.2-13 \mathrm{~km}$ below sea level (b.s.l.) according to seismic investigations (Gallart et al., 1999; Fontaine et al., 2015). A $<3 \mathrm{~km}$-thick layer of dense material interpreted as the underplating of ultramafic rocks between the crust and the mantle lithosphere was inferred by geophysical studies (Charvis et al., 1999; Fontaine et al., 2015). The island is composed by two volcanic edifices (Piton des Neiges: $3070 \mathrm{~m}$ a.s.1 and PdF: $2632 \mathrm{~m}$ a.s.1.) that emitted geochemically similar magmas of the transitional series (Upton and Wadsworth, 1966).

The currently active volcano is the PdF, whose activity began ca. 530 kyrs ago on the southwest flank of the Piton des Neiges volcano (Gillot and Nativel, 1989). Basalts are the only products of $\mathrm{PdF}$ activity and they are inferred to originate from partial melting of the upper mantle (4 GPa; Fretzdorff and Haase, 2002). The mantle source 
was described as homogeneous with constant noble gases and Sr-Nd-Hf-Os isotope signature (Graham et al., 1990; Staudacher et al., 1990; Albarède et al., 1997; Hanyu et al., 2001; Schiano et al., 2012; Peters et al., 2016). Only minor isotope variations are documented in the eruptive products and have been attributed to either (1) a distinct component intrinsic to the plume itself or to the incorporation of the ambient Indian asthenosphere into the upwelling plume (Pietruszka et al., 2009; Di Muro et al., 2014; Vlastelic and Pietruzska, 2016), and/or (2) small degrees of late-stage crustal contamination (Luais, 2004; Pietruszka et al., 2009). All basalts of PdF belong to the transitional series (Upton \& Wadsworth, 1966; Albarède et al., 1997; Boivin and Bachèlery, 2009), with the exception of old evolved alkaline basalts bearing abundant plagioclase (Valer et al., 2017a).

Since 1640 (i.e., the beginning of permanent colonization of the island), most of the PdF eruptions (>95\%) occurs inside the Enclos Fouqué caldera (Fig. 1; Villeneuve and Bachèlery, 2006; Michon et al., 2015), formed between $\sim 5.5$ and $\sim 3.0$ kyrs BP during the Bellecombe explosive events (Ort et al., 2016). There, seismic hypocenters are mostly located at crustal depth (i.e. from $0.5 \mathrm{~km}$ a.s.1. to $11 \mathrm{~km}$ b.s.1.) consistent with the presence of several shallow crustal reservoirs (Nercessian et al., 1996; Di Muro et al., 2014; Coppola et al., 2017). The Enclos Fouqué cliff marks a geomorphological limit between the central activity inside the caldera and the peripheral activity outside it (Fig. 1). The peripheral activity ( $<5 \%$ of historical eruptions) is mainly concentrated within three converging rift zones:

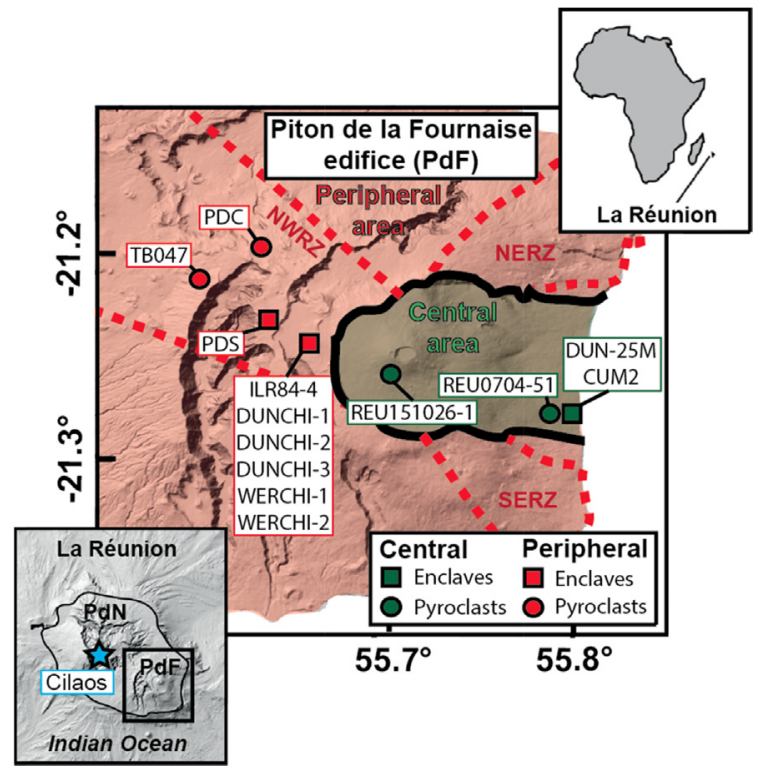

Fig. 1. Location of sampled sites (PdF for Piton de la Fournaise and PdN for Piton des Neiges) and of Cilaos free gases. TB047: Trous Blancs lapilli. PDC: Piton de Caille lapilli. PDS: dunite from Piton du Pas des Sables. ILR84-4: harzburgite from Piton Chisny. DUNCHI-1/2/3: dunites from Piton Chisny. WERCHI-1/2: wehrlites from Piton Chisny. CUM2: subaerial dunite sample from the April 2007 eruption. DUN-25M: submarine dunite sample (25 m bsl) from the April 2007 eruption. REU0704-51: 5th April 2007 lapilli. REU151026-1: 26th October 2015 scoria. the SE rift zone (SERZ), the NE rift zone (NERZ) and the NW rift zone (NWRZ). SERZ and NERZ are almost aseismic and are mostly related to lateral magma transfers from the shallow part of the central plumbing system (Michon et al., 2015). Conversely the NWRZ, which connects the old $\mathrm{PdN}$ volcanic edifice with the western flank of PdF volcano is characterized by deep seismicity located within the lithospheric mantle $(>11 \mathrm{~km}$ b.s.l.). Petrological studies highlight that melts erupted within the NWRZ are more primitive and richer in gas than evolved and degassed melts usually erupted in the central area (Bureau et al., 1998; Di Muro et al., 2014, 2016; Coppola et al., 2017). At least two main zones of magma ponding were inferred within the upper mantle below the PdF volcano and they have been linked to eruptions occuring within the NWRZ. The deepest one ( $\approx 30-35 \mathrm{~km}$-depth), holds rare petrological evidences, and has been inferred by seismic studies (Gallart et al., 1999; Massin, 2009; Fontaine et al., 2015) and modeling of stress fields related to the edifice loading (Gerbault et al., 2017). The second one corresponds to the geophysically defined underplating layer $(\approx 15 \mathrm{~km}$ b.s. 1.) and is in accordance with most of the barometric data obtained on NWRZ eruptive products (Bureau et al., 1998; Boudoire, 2017). Based on the spatio-temporal location of recent seismic hypocenters, some authors have proposed that central crustal reservoirs are fed by lateral transfers of melts at mantle level below the NWRZ, starting from a $30 \mathrm{~km}$-deep offset deep plumbing system located between PdF and Piton des Neiges volcanoes (Michon et al., 2015; Boudoire et al., 2017a, 2017b). Interestingly, this zone located between both volcanic edifices is also set by the highest soil $\mathrm{CO}_{2}$ fluxes, which contrasts with the weakness of inter-eruptive gas emissions in the central area (Liuzzo et al., 2015; Di Muro et al., 2016).

\section{SAMPLES AND METHODS}

In this study, we target fast quenched eruptive products and ultramafic enclaves from both the central and the peripheral (NWRZ) area of PdF (Fig. 1). Eruptive products from the peripheral area are olivine phenocrysts from Piton de Caille (PDC; $<5$ kyrs) and Trous Blancs (TB047; <10 kyrs) tephras. These products were targeted due to (1) the negligible amount of recycled xenocrysts and (2) their geochemical signature (major and traces elements, $\mathrm{Sr}-\mathrm{Nd}$ isotopes) spanning the geochemical variability of recent $\mathrm{PdF}$ magma (Valer, 2016). Similarly, in order to limit the effect of crystal recycling, we selected among the products from the central area a set of olivine microphenocrysts from the 5th April 2007 and of phenocrysts from the 26th October 2015 eruptions. These products are representative of the largest recent eruptions of $\mathrm{PdF}$ and were emitted during the most intense phases of activity (Di Muro et al., 2014; Coppola et al., 2017).

Investigated olivine and clinopyroxenes crystals in enclaves from the NWRZ peripheral area are dunites (DUNCHI-1/2/3), wehrlites (WERCHI-1/2) and harzburgite (ILR84-4) from Piton Chisny ( $\approx 381 \mathrm{yrs} \mathrm{BP}$ ) and Piton du Pas des Sables cone ( $>5$ kyrs). Enclaves from the central area are dunites from the April 2007 eruption, with 
one subaerial (CUM2) and one submarine sample (DUN-25M; $25 \mathrm{~m} \mathrm{bsl}$ ).

The complete description of the analytical procedures used in this study (instrumentations, methodology, calculations, uncertainty and accuracy) is reported as Supplemental Information (Appendix A). The procedure of sample preparation and analysis for noble gases, TGC and carbon isotopes is also described in Martelli et al. (2014), Rizzo et al. (2015), Gennaro et al. (2017), and Robidoux et al. (2017). Below, we summarize the different methods used in this study to perform both the petrological and geochemical analyses.

Olivine and clinopyroxene crystals were handpicked from 13 samples previously fragmented and sieved in the size fractions of 0.5 and $1 \mathrm{~mm}$.

Fluid inclusions (FIs) were analyzed for their composition with a Horiba T64000 Raman spectrometer manufactured by Jobin-Yvon with a 1800 grooves/mm gratings at IPGP (Paris, France). An argon ion laser at $488 \mathrm{~nm}$ wavelength was used at room temperature. Detailed descriptions of the composition of each fluid inclusion and of the procedure used for barometric calculations are reported in Supplemental Information (Appendices A and B).

Electron microprobe analyses on minerals chemistry were performed by using a CAMECA SX5 at Camparis (Paris, France). Further details are reported in Supplemental Information (Appendix A).

In total, 29 measurements have been carried out for noble gases and Total Gas Content (TGC), the latter being almost only $\mathrm{CO}_{2}$ ("noble gases protocol"; more details are given in the text). These analyses were performed at the noble gas isotope laboratory of INGV, Sezione di Palermo (Italy). Helium $\left({ }^{3} \mathrm{He}\right.$ and $\left.{ }^{4} \mathrm{He}\right)$ isotopes were measured separately by two different split-flight-tube mass spectrometers (Helix SFT-Thermo). Argon isotopes $\left({ }^{36} \mathrm{Ar},{ }^{38} \mathrm{Ar}\right.$, and $\left.{ }^{40} \mathrm{Ar}\right)$ were analyzed by a multicollector mass spectrometer (GVI Argus). The moles of TGC of the fluids trapped in the crystals were quantified by measuring the total pressure of gas (by an IONIVAC Transmitters ITR 90) released during crushing in a known volume of the system.

A total of 30 measurements of the abundance and isotope composition of $\mathrm{CO}_{2}$ were performed (" $\delta{ }^{13} \mathrm{C}$ protocol"). The moles of $\mathrm{CO}_{2}$ released from crushing and purified from other components with cryogenic technique were quantified by measuring the pressure of gas within a section of a glass line with a known volume $\left(\sim 16 \mathrm{~cm}^{3}\right)$ using a 626B Baratron ${ }^{\circledR}$ Absolute Capacitance Manometer made by MKS. The determination of ${ }^{13} \mathrm{C} /{ }^{12} \mathrm{C}\left(\mathrm{CO}_{2}\right)$ isotope ratio (expressed as $\delta^{13} \mathrm{C}$ vs V-PDB) has been carried out by Thermo (Finnigan) Delta Plus XP CF-IRMS connected to a Trace GC gas chromatograph and a Thermo (Finnigan) $\mathrm{GC} / \mathrm{C}$ III interface installed at the INGV-Palermo Stable Isotope Laboratory.

\section{RESULTS}

\subsection{Petrology}

\subsubsection{Mineral chemistry in transitional lavas and enclaves}

In samples from the central area, the composition of olivines (core and rims) from both pyroclasts and enclaves is consistent with the most magnesian mode $\left(\mathrm{Fo}_{84}\right)$ found in recent PdF central products (Fig. 2; Boivin and Bachèlery, 2009; Di Muro et al., 2016). We find that olivines in peripheral pyroclasts are more magnesian $\left(\mathrm{Fo}_{85.5-86}\right)$ than central ones, consistently with previous findings (Bureau et al., 1998). The composition of olivines in peripheral enclaves spans a range from $\mathrm{Fo}_{84}$ (DUNCHI-2) to $\mathrm{Fo}_{86.5}$ (DUNCHI-1) consistent with previous results on similar samples (Brugier, 2016).

Calcium contents in olivines cover a large range, from low-Ca olivines $(\mathrm{CaO}<0.1 \mathrm{wt} \%)$ to high-Ca olivines $(>0.4 \mathrm{wt} \%)$. Highest calcium contents are found in olivines of central pyroclasts and enclaves $(0.38-0.41 \mathrm{wt} \%)$ and represent the highest $\mathrm{Ca}$ contents identified in $\mathrm{PdF}$ olivines

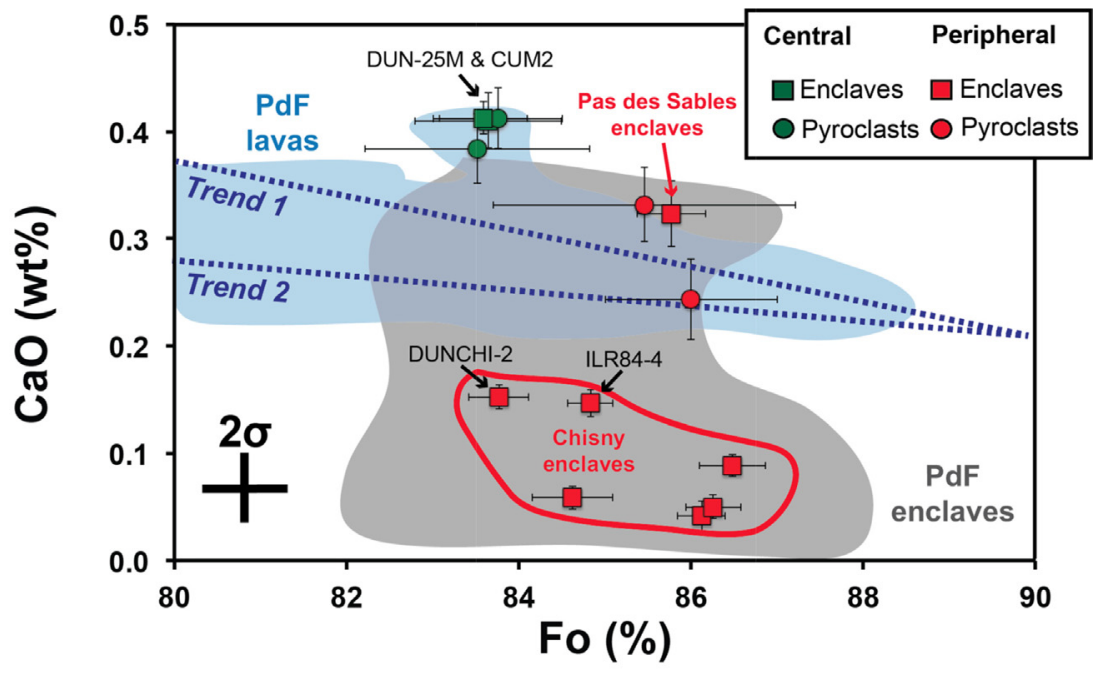

Fig. 2. Forsterite $(\mathrm{mol} \%)$ vs. $\mathrm{CaO}$ content $(\mathrm{wt} \%)$ in olivines hosting the fluid inclusions described in this study. Filled blue and grey fields represent published compositions of olivines from PdF lavas and enclaves, respectively (Di Muro et al., 2015, 2016; Brugier, 2016). (For interpretation of the references to color in this figure legend, the reader is referred to the web version of this article.) 
(Fig. 2). Olivines from peripheral pyroclasts and from the Piton des Sables dunite (PDS) have a lower $\mathrm{CaO}$ content with respect to central ones and fall close to the two trends (Trend 1 - high Ca and Trend 2 - low Ca on Fig. 2) that were previously recognized in PdF lavas (Di Muro et al., 2014). On the contrary, the main particularity of our dataset is that all olivines from Chisny enclaves present a strong depletion in calcium $(<0.15 \mathrm{wt} \%)$ irrespective to their forsterite contents (from $\mathrm{Fo}_{84.5}$ to $\mathrm{Fo}_{86.5}$ ). Their composition falls in the lowest range of previously reported analyses (Fig. 2; Brugier, 2016).

\subsubsection{Fluid inclusions in olivine crystals}

Optically-resolvable FIs in olivine crystals studied here cover a large size range, from a few micrometers or less up to $100 \mu \mathrm{m}$ in DUN-25M (Fig. 3). In olivines from both central and peripheral pyroclasts, their diameter rarely exceeds 1-2 $\mu \mathrm{m}$ (Supplemental Information: Fig. C1 in Appendix C). Conversely, a larger average size is observed in olivines from enclaves, mainly varying between 1 and $2 \mu \mathrm{m}$ and $20 \mu \mathrm{m}$ (up to $100 \mu \mathrm{m}$ in DUN-25M). Following the nomenclature of Roedder (1984), we identify primary FIs (Fig. 3a) in olivines from peripheral and central pyroclasts (Table 1; REU151026-1a; TB047) and more rarely in olivines from enclaves (DUN-25M). Most of the FIs in olivine crystals from both central and peripheral enclaves are secondary FIs (multiple small FIs distributed along healed fractures that crosscut the entire crystal; Fig. 3b) and are sometimes associated with primary FIs (Table 1; PDS; WERCHI-1). Interestingly, in crystals hosting both types of FIs (e.g. PDS; WERCHI-1), neither compositional nor $\mathrm{CO}_{2}$ densities differences were observed among small $(<5 \mu \mathrm{m})$ FIs, independently of their primary or secondary origin.

No empty FIs were detected during Raman analysis. Only FIs smaller than $5 \mu \mathrm{m}$ having a well-rounded shape without visible daughter minerals have been analysed following the recommendations of Frezzotti and Touret (2014). Large FIs $(>5 \mu \mathrm{m})$ have often an irregular shape with optical evidences of daughter minerals which suggest the occurrence of post-trapping modification processes (Wanamaker and Evans, 1989; Frezzotti and Touret, 2014).

For each analysed FI, the low frequency region $(<1500$ $\left.\mathrm{cm}^{-1}\right)$ of Raman spectra (200-4000 $\mathrm{cm}^{-1}$; Supplemental Information: Appendix B) shows the occurrence of bands related to (1) the main vibrational frequencies of the host crystal (i.e. olivine here; green arrows in Fig. 3) and, (2) the Fermi dyad resonance lines of gaseous $\mathrm{CO}_{2}$ used for barometric purposes (1285 and $\left.1388 \mathrm{~cm}^{-1}\right)$, together with the two shoulder peaks called "hot bands".

In spite of the absence of visible daughter minerals, Raman spectra reveal the presence of microscopic solid phases in many FIs $\left(1000-1500 \mathrm{~cm}^{-1}\right.$; Supplemental Information: Appendix B):

(1) Narrow bands $\left(1083-1090 \mathrm{~cm}^{-1}\right)$, which can be attributed to $\mathrm{Mg}-\mathrm{Ca}$ carbonate peaks and possibly to magnesite $\left(\mathrm{MgCO}_{3} ; 1093 \mathrm{~cm}^{-1}\right.$; Fig. 3b). These FIs mostly occur in crystals from Piton Chisny enclaves and TB047 peripheral pyroclasts. In other samples, we frequently observe weak narrow bands at $1042-1044 \mathrm{~cm}^{-1}$ and $1057 \mathrm{~cm}^{-1}$ that are tentatively attributed to other $\mathrm{C}$-bearing phases as nahcolite $\left(\mathrm{NaHCO}_{3}\right)$ and/or variably hydrous carbonates (Ruff spectral database),

(2) Narrow bands in the range $1013-1038 \mathrm{~cm}^{-1}$ are attributed to sulfates. They were detected in FIs hosted in crystals of CUM2, PDS (Fig. 3a) and peripheral clinopyroxene-bearing enclaves (WERCHI1-2). A narrow peak at $1150 \mathrm{~cm}^{-1}$ attributed to gaseous $\mathrm{SO}_{2}$ was only observed in FIs of DUN-25M (Fig. 3c).

In the high frequency region $\left(>1500 \mathrm{~cm}^{-1}\right)$, we identified three groups of spectra with either (1) a flat high frequency region (Fig. 3a; PDS); (2) a broad asymmetric band at $3430-3463 \mathrm{~cm}^{-1}$ and a weaker band at $3189-3192 \mathrm{~cm}^{-1}$ (Fig. 3b; DUNCHI-1 and essentially in Piton Chisny enclaves) that can be attributed to an aqueous phase $\left(\mathrm{H}_{2} \mathrm{O} \pm \mathrm{CO}_{2} \pm\right.$ salts) and; (3) a flat high frequency region with several weak narrow peaks $\left(3159,3222\right.$ and $3466 \mathrm{~cm}^{-1}$ for the most frequent) possibly related to an hydrous crystalline phase. Peaks related to interference of epoxy were clearly identified in a few samples (DUN-25M, CUM2, DUNCHI-1; Fig. 3c). Even if no narrow peak linked to water vapor $\left(3640 \mathrm{~cm}^{-1}\right)$ was found in any sample, we cannot exclude that low amount of water vapor might occur in the fluid inclusions.

\subsection{Geochemistry of fluid inclusions}

\subsection{1. $\mathrm{He}-\mathrm{Ar}-\mathrm{CO}_{2}$ systematics}

Helium, argon, carbon dioxide abundances and Total Gas Content (TGC) obtained by crystal crushing are given in Table 2. Good reproducibility is observed between replicates. Here we describe the general behavior of gas abundance between central and peripheral products and between pyroclasts and enclaves.

Helium abundance, here designated as ${ }^{4} \mathrm{He}$, varies from $3.2 \times 10^{-13} \mathrm{~mol} \mathrm{~g}^{-1}$ (ILR84-4) to $2.9 \times 10^{-11} \mathrm{~mol} \mathrm{~g}^{-1}$ (REU151026-1) (Fig. 4). Pyroclasts and enclaves (CUM2) erupted in the central area show the lowest abundances $\left(<9 \times 10^{-13} \mathrm{~mol} \mathrm{~g}^{-1}\right)$. Pyroclasts emitted in the peripheral area on the volcano flanks are He-richer (up to $5 \times 10^{-12}$ $\mathrm{mol} \mathrm{g}^{-1}$ ) and the highest contents are measured in enclaves from the peripheral area $\left(>4 \times 10^{-12} \mathrm{~mol} \mathrm{~g}^{-1}\right)$.

The ${ }^{40} \mathrm{Ar} /{ }^{36} \mathrm{Ar}$ varies from 322 to 5226 , which for most of the samples is sensibly higher than the atmospheric signature $\left({ }^{40} \mathrm{Ar} /{ }^{36} \mathrm{Ar}=295.5\right)$. However, a correction from atmospheric contamination is necessary in order to obtain the so-called magmatic-derived ${ }^{40} \mathrm{Ar}^{*}$. This has been calculated, accordingly with the following formula that assumes that all the measured ${ }^{36} \mathrm{Ar}$ is of atmospheric origin:

$$
{ }^{40} \mathrm{Ar}^{*}={ }^{40} \mathrm{Ar}_{\mathrm{m}}-\left(\left({ }^{40} \mathrm{Ar} /{ }^{36} \mathrm{Ar}\right) \text { air } \times{ }^{36} \mathrm{Ar}_{\mathrm{m}}\right)
$$

where ${ }^{40} \mathrm{Ar}^{*}$ represents the corrected ${ }^{40} \mathrm{Ar}$, and the " $m$ " subscript indicates "measured". The recalculated ${ }^{40} \mathrm{Ar}^{*}$ ranges from $9 \times 10^{-14} \mathrm{~mol} \mathrm{~g}^{-1}$ (REU151026-1) to $2 \times 10^{-11} \mathrm{~mol} \mathrm{~g}^{-1}$ (ILR84-4; harzburgite). Like the ${ }^{4} \mathrm{He}$ abundance, ${ }^{40} \mathrm{Ar}^{*}$ contents generally increase from pyroclasts and enclaves 


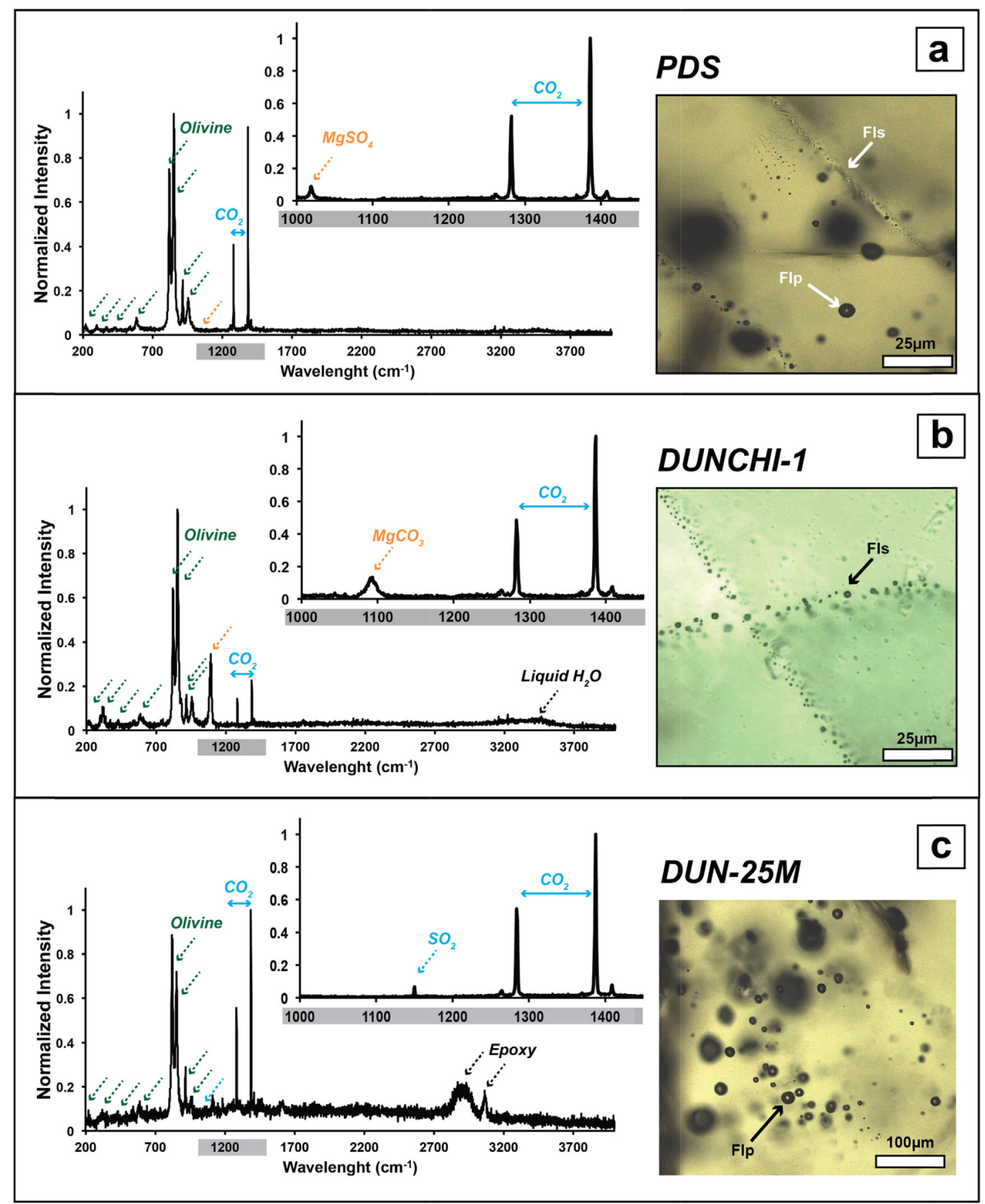

Fig. 3. Microphotographs and normalized Raman spectra $\left(200-4000 \mathrm{~cm}^{-1}\right)$ of fluid inclusions. (a) Primary and secondary fluid inclusions in olivines of PDS. (b) Trails of small secondary fluid inclusions in olivines from DUNCHI-1. (c) Large primary fluid inclusions in olivines of DUN-25M. FIp: primary fluid inclusion. FIs: secondary fluid inclusion. Green arrows: Raman bands of the host crystal (olivine). Orange arrows: Raman bands of secondary mineral phases within fluid inclusions (mainly carbonates and sulfates). Light blue arrows: Raman bands of gaseous species. Black arrows: Raman bands of liquid $\mathrm{H}_{2} \mathrm{O}$ and epoxy in the high frequency region $\left(>1500 \mathrm{~cm}^{-1}\right)$. (For interpretation of the references to color in this figure legend, the reader is referred to the web version of this article.)

of the central area $\left(<7.6 \times 10^{-12} \mathrm{~mol} \mathrm{~g}^{-1}\right)$ to pyroclasts emitted on the volcano flanks $\left(\sim 2 \times 10^{-12} \mathrm{~mol} \mathrm{~g}^{-1}\right)$ (Fig. 4a). Highest ${ }^{40} \mathrm{Ar}^{*}$ abundances are found in peripheral enclaves $\left(>4 \times 10^{-12} \mathrm{~mol} \mathrm{~g}^{-1}\right)$. The ${ }^{4} \mathrm{He}^{40} \mathrm{Ar}^{*}$ varies in the range between 0.7 and 8.5 , which is slightly wider than that of the typical production ratio of the mantle $\left({ }^{4} \mathrm{He} /{ }^{40} \mathrm{Ar}^{*}=\right.$ 1-5; e.g., Ozima and Podosek, 1983; Marty, 2012).

$\mathrm{CO}_{2}$ concentration (from TGC) ranges from $9 \times 10^{-10}$ mol g${ }^{-1}$ (CUM2) to $8 \times 10^{-7} \mathrm{~mol} \mathrm{~g}^{-1}$ (ILR84-4) (Fig. 4b). The lowest contents are found in pyroclasts and rare 


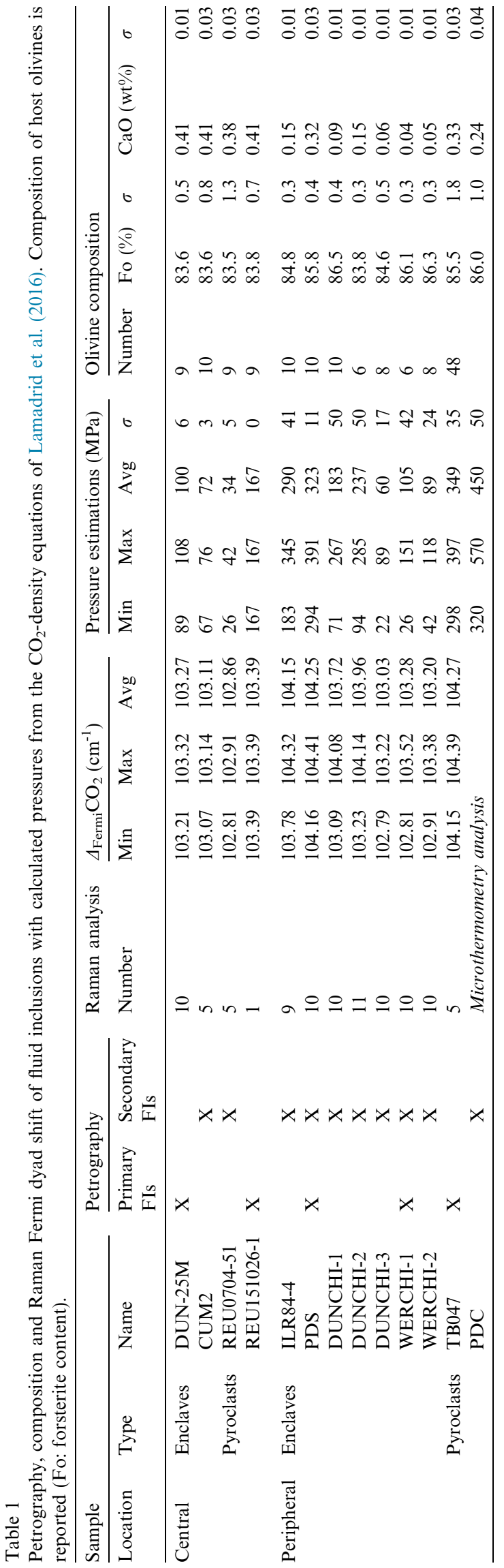

enclaves from the central area $\left(<1 \times 10^{-9} \mathrm{~mol} \mathrm{~g}^{-1}\right)$. Intermediate abundances are found in peripheral pyroclasts $(2-3 \times$ $10^{-8} \mathrm{~mol} \mathrm{~g}^{-1}$ ) whereas the highest values are set in peripheral enclaves $\left(>3 \times 10^{-8} \mathrm{~mol} \mathrm{~g}^{-1}\right)$. As reflected by ${ }^{4} \mathrm{He},{ }^{40} \mathrm{Ar}^{*}$ and $\mathrm{CO}_{2}$ abundances, the TGC released by crystal crushing during noble gases analysis increases from central to peripheral products (Table 2). The only exception is given by DUN$25 \mathrm{M}$ central enclave, a fast quenched sample recovered from a depth of $25 \mathrm{~m}$ below sea level that has a gas abundance $\left(4 \times 10^{-7} \mathrm{~mol} \mathrm{~g}^{-1}\right)$ in the range of peripheral products, close to the maximum value measured in our dataset $\left(8 \times 10^{-7} \mathrm{~mol} \mathrm{~g}^{-1}\right.$; ILR84-4) (Table 2; Fig. 6c).

In our samples, ${ }^{4} \mathrm{He}$ vs. ${ }^{40} \mathrm{Ar}^{*}$ and ${ }^{4} \mathrm{He}$ vs. $\mathrm{CO}_{2}$ are well fitted by power functions $\left(r^{2}=0.95\right.$ and 0.96 , respectively; Fig. 4). With the exception of DUN-25M, it confirms the gas depletion in central products with respect to peripheral ones. It is worth noting that DUNCHI-1, DUNCHI-2 and DUN-25M are the only samples falling out of the $95 \%$-confidence interval defined by the power functions. We note that previous analyses performed on Piton Chisny peripheral enclaves (Trull et al., 1993) present a maximum ${ }^{4} \mathrm{He}$ content $\left(3.0 \times 10^{-11} \mathrm{~mol} \mathrm{~g}{ }^{-1}\right.$; black squares on Fig. 4b) that is similar to the one we document in our study $\left(2.9 \times 10^{-11} \mathrm{~mol} \mathrm{~g}^{-1}\right)$. Meanwhile, $\mathrm{CO}_{2}$ content strongly differs between both studies. For instance, for ILR84-4, we measure a content of $7.8 \times 10^{-7} \mathrm{~mol} \mathrm{~g}^{-1}$ that is lower than the value of $3.9 \times 10^{-6} \mathrm{~mol} \mathrm{~g}^{-1}$ reported by Trull et al. (1993). We argue that the observed discrepancy in the $\mathrm{CO}_{2}$ estimations could be due to the distinct analytical protocols (Kendrick and Phillips, 2009). Actually, ${ }^{4} \mathrm{He}$ contents reported by Trull et al. (1993) refer to crystal crushing measurements performed by Staudacher et al. (1990) whereas $\mathrm{CO}_{2}$ contents were determined by step-heating procedure.

\subsubsection{Carbon isotope composition of $\mathrm{CO}_{2}$}

Single (or individual) measurement of $\mathrm{CO}_{2}$ concentrations and $\delta^{13} \mathrm{C}$ values obtained by the replicates for each sample are reported in Table 3. Average value and standard deviation data are also reported in Table 2. A good reproducibility is observed between $\mathrm{CO}_{2}$ estimations from the " $\delta{ }^{13} \mathrm{C}$ protocol" and the "noble gases protocol" (Supplemental Information: Fig. C2 in Appendix C). Importantly, a good reproducibility is also observed between replicates regarding both $\mathrm{CO}_{2}$ concentrations and $\delta^{13} \mathrm{C}$ values.

The $\delta^{13} \mathrm{C}$ values span a broad range from $-11.3 \%$ in pyroxene from WERCHI-1 to $-1.8 \%$ in olivine from DUN-25M (Fig. 7). This range of values is comparable to that reported by Trull et al. (1993) $\left(-10.2 \%_{0}<\delta^{13} \mathrm{C}\right.$ $<-3.7 \%$ ). These authors found that the lowest isotopic values are only observed in clinopyroxene from Chisny wehrlitic enclaves $(-10.2 \%$ ), while olivines have less negative $\delta^{13} \mathrm{C}$ in agreement with our measurements. We note that the measurements we made in clinopyroxene from WERCHI-2 (-3.7\%o) does not show a ${ }^{13} \mathrm{C}$ depletion like in WERCHI-1. These values while fall within the range of $\delta^{13} \mathrm{C}$ values found in olivines $(-2.6 \%$ to $-4.6 \%$ ) reported for other enclaves in this study and by Trull et al. (1993). Lower values are obtained for peripheral pyroclasts $(-5 \%$ in $\mathrm{TB} 047$ and $-6.4 \%$ in PDC). 
Table 2

$\mathrm{He}-\mathrm{Ar}-\mathrm{CO}_{2}$ contents, total gas content (TGC), and relative ratios from the "noble gas protocol" (see Section 3 ). $\delta^{13} \mathrm{C}$ measurements and corresponding $\mathrm{CO} 2$ contents from the $\delta^{13} \mathrm{C}$ protocol (see Section 3). Individual carbon isotopic measurements are reported in Table 3. Number $=$ number of replicates. $\sigma=$ standard deviation of replicates measurements.

\begin{tabular}{|c|c|c|c|c|c|c|c|c|c|c|c|}
\hline \multicolumn{3}{|l|}{ Sample } & \multicolumn{9}{|c|}{ Gas Contents } \\
\hline Location & Type & Name & Number & $\begin{array}{l}{ }^{4} \mathrm{He} \\
\left(\mathrm{mol} \mathrm{g}^{-1}\right)\end{array}$ & $\sigma$ & $\begin{array}{l}{ }^{40} \mathrm{Ar}^{*} \\
\left(\mathrm{~mol} \mathrm{~g}^{-1}\right)\end{array}$ & $\sigma$ & $\begin{array}{l}\text { TGC } \\
\left(\mathrm{mol} \mathrm{g}^{-1}\right)\end{array}$ & $\sigma$ & $\begin{array}{l}\mathrm{CO}_{2} \\
\left(\mathrm{~mol} \mathrm{~g}^{-1}\right)\end{array}$ & $\sigma$ \\
\hline \multirow[t]{4}{*}{ Central } & Enclaves & DUN-25M & 3 & $6.92 \mathrm{E}-12$ & $1.62 \mathrm{E}-12$ & $7.58 \mathrm{E}-12$ & $1.49 \mathrm{E}-12$ & $3.79 \mathrm{E}-07$ & $1.16 \mathrm{E}-07$ & $3.78 \mathrm{E}-07$ & $1.16 \mathrm{E}-07$ \\
\hline & & CUM2 & 1 & $5.85 \mathrm{E}-13$ & & $1.31 \mathrm{E}-13$ & & $1.00 \mathrm{E}-09$ & & $9.06 \mathrm{E}-10$ & \\
\hline & Pyroclasts & REU0704-51 & 1 & $8.55 \mathrm{E}-13$ & & $1.00 \mathrm{E}-13$ & & $1.37 \mathrm{E}-09$ & & $1.34 \mathrm{E}-09$ & \\
\hline & & REU151026-1 & 2 & $3.24 \mathrm{E}-13$ & $9.35 \mathrm{E}-14$ & $9.01 \mathrm{E}-14$ & $7.38 \mathrm{E}-15$ & $1.06 \mathrm{E}-09$ & $6.28 \mathrm{E}-10$ & $1.04 \mathrm{E}-09$ & $6.27 \mathrm{E}-10$ \\
\hline \multirow[t]{9}{*}{ Peripheral } & Enclaves & ILR84-4 & 1 & $2.89 \mathrm{E}-11$ & & $2.02 \mathrm{E}-11$ & & $7.81 \mathrm{E}-07$ & & $7.81 \mathrm{E}-07$ & \\
\hline & & PDS & 2 & $7.38 \mathrm{E}-12$ & $7.86 \mathrm{E}-13$ & $5.27 \mathrm{E}-12$ & $8.93 \mathrm{E}-13$ & $1.82 \mathrm{E}-07$ & $1.87 \mathrm{E}-08$ & $1.76 \mathrm{E}-07$ & $1.80 \mathrm{E}-08$ \\
\hline & & DUNCHI-1 & 2 & $1.81 \mathrm{E}-11$ & $6.99 \mathrm{E}-13$ & $1.10 \mathrm{E}-11$ & $5.64 \mathrm{E}-13$ & $3.02 \mathrm{E}-08$ & $1.16 \mathrm{E}-09$ & $2.91 \mathrm{E}-08$ & $1.05 \mathrm{E}-09$ \\
\hline & & DUNCHI-2 & 2 & $8.12 \mathrm{E}-12$ & $3.52 \mathrm{E}-12$ & $1.13 \mathrm{E}-11$ & $6.82 \mathrm{E}-13$ & $1.50 \mathrm{E}-08$ & $6.42 \mathrm{E}-10$ & $1.38 \mathrm{E}-08$ & $5.17 \mathrm{E}-10$ \\
\hline & & DUNCHI-3 & 2 & $6.52 \mathrm{E}-12$ & $6.36 \mathrm{E}-13$ & $5.94 \mathrm{E}-12$ & $7.68 \mathrm{E}-13$ & $3.43 \mathrm{E}-08$ & $5.19 \mathrm{E}-09$ & $3.39 \mathrm{E}-08$ & $5.17 \mathrm{E}-09$ \\
\hline & & WERCHI-1 & 3 & $6.54 \mathrm{E}-12$ & $3.05 \mathrm{E}-12$ & $3.97 \mathrm{E}-12$ & $2.54 \mathrm{E}-12$ & $4.90 \mathrm{E}-08$ & $3.66 \mathrm{E}-08$ & $4.88 \mathrm{E}-08$ & $3.66 \mathrm{E}-08$ \\
\hline & & WERCHI-2 & 1 & $4.61 \mathrm{E}-12$ & & $4.03 \mathrm{E}-12$ & & $3.41 \mathrm{E}-08$ & & $3.26 \mathrm{E}-08$ & \\
\hline & Pyroclasts & ТВ047 & 2 & $4.95 \mathrm{E}-12$ & $1.40 \mathrm{E}-13$ & $2.51 \mathrm{E}-12$ & $2.87 \mathrm{E}-13$ & $2.89 \mathrm{E}-08$ & $3.18 \mathrm{E}-09$ & $2.83 \mathrm{E}-08$ & $3.70 \mathrm{E}-09$ \\
\hline & & PDC & 7 & $3.66 \mathrm{E}-12$ & $7.71 \mathrm{E}-13$ & $1.86 \mathrm{E}-12$ & $5.89 \mathrm{E}-13$ & $2.32 \mathrm{E}-08$ & $1.57 \mathrm{E}-08$ & $2.29 \mathrm{E}-08$ & $1.57 \mathrm{E}-08$ \\
\hline \multicolumn{3}{|l|}{ Sample } & \multicolumn{4}{|l|}{ Ratios } & \multicolumn{5}{|l|}{ Carbon } \\
\hline Location & Type & Name & ${ }^{4} \mathrm{He} /{ }^{40} \mathrm{Ar}^{*}$ & $\sigma$ & ${ }^{4} \mathrm{He} / \mathrm{CO}_{2}$ & $\sigma$ & Number & $\begin{array}{l}\mathrm{CO}_{2} \\
\left(\mathrm{~mol} \mathrm{~g}^{-1}\right)\end{array}$ & $\sigma$ & $\begin{array}{l}\delta^{13} \mathrm{C} \\
(\%)\end{array}$ & $\sigma$ \\
\hline \multirow[t]{4}{*}{ Central } & Enclaves & DUN-25M & 0.91 & 0.04 & $1.88 \mathrm{E}-05$ & $1.82 \mathrm{E}-06$ & 6 & $4.04 \mathrm{E}-07$ & $1.03 \mathrm{E}-07$ & -2.6 & 0.5 \\
\hline & & CUM2 & 4.45 & & $5.85 \mathrm{E}-04$ & & & & & & \\
\hline & Pyroclasts & REU0704-51 & 8.53 & & $6.24 \mathrm{E}-04$ & & & & & & \\
\hline & & REU151026-1 & 3.54 & 0.75 & $3.93 \mathrm{E}-04$ & $1.45 \mathrm{E}-04$ & & & & & \\
\hline \multirow[t]{9}{*}{ Peripheral } & Enclaves & ILR84-4 & 1.43 & & $3.70 \mathrm{E}-05$ & & 5 & $5.96 \mathrm{E}-07$ & $1.24 \mathrm{E}-07$ & -3.2 & 0.1 \\
\hline & & PDS & 1.42 & 0.09 & $4.06 \mathrm{E}-05$ & $1.46 \mathrm{E}-07$ & 3 & $1.47 \mathrm{E}-07$ & $4.99 \mathrm{E}-08$ & -3.1 & 0.4 \\
\hline & & DUNCHI-1 & 1.68 & 0.04 & $6.29 \mathrm{E}-04$ & $1.04 \mathrm{E}-06$ & 1 & $2.95 \mathrm{E}-08$ & & -3.6 & \\
\hline & & DUNCHI-2 & 0.70 & 0.27 & $5.32 \mathrm{E}-04$ & $2.12 \mathrm{E}-04$ & 2 & $1.29 \mathrm{E}-08$ & $3.37 \mathrm{E}-09$ & -4.6 & 0.1 \\
\hline & & DUNCHI-3 & 1.10 & 0.04 & $1.92 \mathrm{E}-04$ & $1.04 \mathrm{E}-05$ & 3 & $3.19 \mathrm{E}-08$ & $3.26 \mathrm{E}-09$ & -3.8 & 0.4 \\
\hline & & WERCHI-1 & 1.83 & 0.61 & $4.59 \mathrm{E}-04$ & $4.73 \mathrm{E}-04$ & 1 & $5.44 \mathrm{E}-08$ & & -11.3 & \\
\hline & & WERCHI-2 & 1.14 & & $1.35 \mathrm{E}-04$ & & 2 & $6.41 \mathrm{E}-08$ & & -3.7 & 0.6 \\
\hline & Pyroclasts & TB047 & 1.99 & 0.17 & $1.74 \mathrm{E}-04$ & $2.40 \mathrm{E}-05$ & 1 & $2.57 \mathrm{E}-08$ & & -5.0 & \\
\hline & & PDC & 2.05 & 0.37 & $1.90 \mathrm{E}-04$ & $5.66 \mathrm{E}-05$ & 6 & $9.64 \mathrm{E}-08$ & $3.84 \mathrm{E}-08$ & -6.4 & 0.5 \\
\hline
\end{tabular}



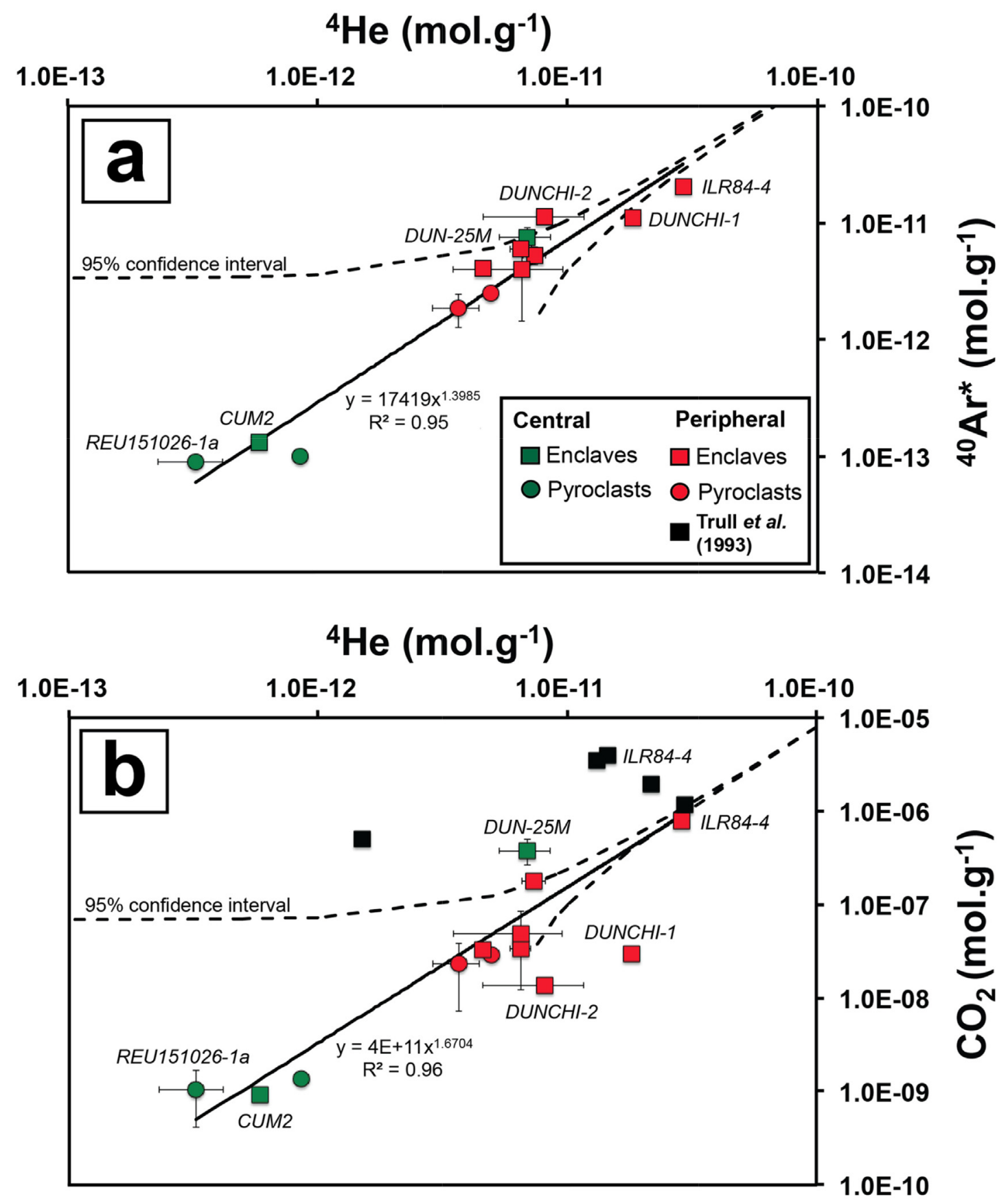

Fig. 4. Gas contents released by crystal crushing and best fitting functions (the $95 \%$ confidence intervals are reported by dashed lines and delimit the field where $95 \%$ of the measured values are expected to fall with respect to the best fitting functions). (a) ${ }^{4} \mathrm{He}$ vs. ${ }^{40} \mathrm{Ar}{ }^{*}$. (b) ${ }^{4} \mathrm{He}$ vs. $\mathrm{CO}_{2} . \mathrm{CO}_{2}$ contents from Trull et al. (1993) (black squares) measurements were obtained by a step-heating procedure whereas He contents refer to crushing measurements on the same samples by Staudacher et al. (1990).

Unfortunately, no measurements were possible in central pyroclasts due to the very low amount of $\mathrm{CO}_{2}$ in these products.

ILR84-4 harzburgite $\left(\delta^{13} \mathrm{C}:-3.2 \%\right.$ ) was also analysed by Trull et al. (1993) that found a similar ratio $\left(\delta^{13} \mathrm{C}\right.$ : $-3.7 \%$ ), the difference falling in the range including both the uncertainty of the analytical procedure and the natural variability of the samples. If $\mathrm{CO}_{2}$ contents measured by step-heating (Trull et al., 1993) are higher than those measured in this study by crystal crushing, $\delta^{13} \mathrm{C}$ values are independent on the used protocol. Consequently, in order to avoid any bias in the following parts, we will take into consideration only $\delta^{13} \mathrm{C}$ values (and not the $\mathrm{CO}_{2}$ contents) documented by these authors. 
Table 3

$\mathrm{CO}_{2}$ contents and $\delta^{13} \mathrm{C}$ from mineral crushing. Average and standard deviation from replicates are reported. Crushed mineral (ol: olivine; px: clinopyroxene) between parenthesis).

\begin{tabular}{|c|c|c|c|c|c|c|c|c|c|}
\hline \multicolumn{3}{|l|}{ Sample } & \multicolumn{3}{|c|}{ Replicates } & \multicolumn{4}{|l|}{ Average } \\
\hline Location & Type & Name & Label & $\begin{array}{l}\mathrm{CO}_{2} \\
\left(\mathrm{~mol} \mathrm{~g}^{-1}\right)\end{array}$ & $\begin{array}{l}\delta^{13} \mathrm{C} \\
(\%)\end{array}$ & $\begin{array}{l}\mathrm{CO}_{2} \\
\left(\mathrm{~mol} \mathrm{~g}^{-1}\right)\end{array}$ & $\sigma$ & $\begin{array}{l}\delta^{13} \mathrm{C} \\
(\%)\end{array}$ & $\sigma$ \\
\hline Central & Enclaves & DUN-25M (ol) & $\begin{array}{l}1 \\
2 \\
3 \\
4 \\
5 \\
6\end{array}$ & $\begin{array}{l}4.52 \mathrm{E}-07 \\
4.21 \mathrm{E}-07 \\
5.78 \mathrm{E}-07 \\
3.09 \mathrm{E}-07 \\
4.06 \mathrm{E}-07 \\
2.55 \mathrm{E}-07\end{array}$ & $\begin{array}{l}-3.3 \\
-2.9 \\
-2.7 \\
-1.8 \\
-2.7 \\
-2.0\end{array}$ & $4.04 \mathrm{E}-07$ & $1.03 \mathrm{E}-07$ & -2.6 & 0.5 \\
\hline Peripheral & Enclaves & ILR84-4 (ol) & $\begin{array}{l}1 \\
2 \\
3 \\
4 \\
5\end{array}$ & $\begin{array}{l}4.67 \mathrm{E}-07 \\
5.74 \mathrm{E}-07 \\
5.14 \mathrm{E}-07 \\
5.95 \mathrm{E}-07 \\
8.27 \mathrm{E}-07\end{array}$ & $\begin{array}{l}-3.1 \\
-3.2 \\
-3.3 \\
-3.3 \\
-3.3\end{array}$ & $5.96 \mathrm{E}-07$ & $1.24 \mathrm{E}-07$ & -3.2 & 0.1 \\
\hline & & $\begin{array}{l}\text { PDS (ol) } \\
\text { DUNCHI-1 (ol) }\end{array}$ & $\begin{array}{l}1 \\
2 \\
3 \\
1\end{array}$ & $\begin{array}{l}2.14 \mathrm{E}-07 \\
9.35 \mathrm{E}-08 \\
1.35 \mathrm{E}-07 \\
2.95 \mathrm{E}-08\end{array}$ & $\begin{array}{l}-3.4 \\
-2.5 \\
-3.5 \\
-3.6\end{array}$ & $1.47 \mathrm{E}-07$ & $4.99 \mathrm{E}-08$ & -3.1 & 0.4 \\
\hline & & DUNCHI-2 (ol) & $\begin{array}{l}1 \\
2\end{array}$ & $\begin{array}{l}1.62 \mathrm{E}-08 \\
9.49 \mathrm{E}-09\end{array}$ & $\begin{array}{l}-4.5 \\
-4.7\end{array}$ & $1.29 \mathrm{E}-08$ & $3.37 \mathrm{E}-09$ & -4.6 & 0.1 \\
\hline & & DUNCHI-3 (ol) & $\begin{array}{l}1 \\
2 \\
3 \\
1\end{array}$ & $\begin{array}{l}3.34 \mathrm{E}-08 \\
2.74 \mathrm{E}-08 \\
3.50 \mathrm{E}-08 \\
5.44 \mathrm{E}-08\end{array}$ & $\begin{array}{l}-3.2 \\
-4.1 \\
-4.0 \\
-11.3\end{array}$ & $3.19 \mathrm{E}-08$ & $3.26 \mathrm{E}-09$ & -3.8 & 0.4 \\
\hline & & WERCHI-2 (px) & $\begin{array}{l}1 \\
2\end{array}$ & $\begin{array}{l}6.41 \mathrm{E}-08 \\
6.41 \mathrm{E}-08\end{array}$ & $\begin{array}{l}-4.3 \\
-3.2\end{array}$ & $6.41 \mathrm{E}-08$ & & -3.7 & 0.6 \\
\hline & Pyroclasts & TB047 (ol) & 1 & $2.57 \mathrm{E}-08$ & -5.0 & & & & \\
\hline & & PDC (ol) & $\begin{array}{l}1 \\
2 \\
3 \\
4 \\
5 \\
6\end{array}$ & $\begin{array}{l}1.31 \mathrm{E}-07 \\
6.10 \mathrm{E}-08 \\
1.62 \mathrm{E}-07 \\
6.20 \mathrm{E}-08 \\
9.58 \mathrm{E}-08 \\
6.66 \mathrm{E}-08\end{array}$ & $\begin{array}{l}-5.5 \\
-6.0 \\
-6.8 \\
-6.4 \\
-6.6 \\
-7.2\end{array}$ & $9.64 \mathrm{E}-08$ & $3.84 \mathrm{E}-08$ & -6.4 & 0.5 \\
\hline
\end{tabular}

\section{DISCUSSION}

\subsection{Inferences on magma ponding zones}

\subsubsection{Crystallization depth}

Entrapment pressures of FIs were estimated from their $\mathrm{CO}_{2}$ density (Table 1; see Methods in Supplemental Information). Since numerous processes can affect the initial $\mathrm{CO}_{2}$ density of FIs and thus modify their pristine pressure, it is generally assumed that the estimated pressure corresponds to the minimum entrapment pressure and depth (Viti and Frezzotti, 2000). In volcanic contexts, the main processes of post-trapping modification and leading to major underestimation of the original density in FIs are: (1) the partial or total fluid leakage, (2) the formation of volatile bearing daughter minerals like carbonates and, (3) volumetric resetting by crystal brittle (decrepitation) or plastic failure (stretching) (Wanamaker and Evans, 1989; Frezzotti and Touret, 2014). These phenomena are mainly dependent on the strength of the mineral host (Wanamaker and Evans, 1989) and on the ascent history (see Hansteen and Klügel (2008) for a complete review). In Supplemental Information (Appendix D), we evaluate their influence on our pressure estimations. More specifically, we point out that (1) fluid leakage is quite limited in our samples set and (2) late-stage carbonates formation only plays a minor role on the estimated densities, close to the uncertainty related to the analytical procedure (Fig. 5). We infer that (3) volumetric resetting processes could be the main factor leading to an underestimation of the initial trapping pressure, and have mainly operated in crystals from enclaves (see below).

Meanwhile, in our study (Table 1), we show that central products (pyroclasts: REU0704-51, REU151026-1; dunite enclaves: CUM2, DUN-25M) record low crustal pressures $(<167 \mathrm{MPa}$ and centered at $80-120 \mathrm{MPa}$; Fig. 5c; Table 1) broadly consistent with previous data (Famin et al., 2009; Di Muro et al., 2016). FIs from central samples sometimes contain S-bearing phases as sulfates (CUM2), consistent with the exsolution of sulfur species at shallow pressure $(<200 \mathrm{MPa})$ due to the high solubility of sulfur in PdF basaltic melts (Di Muro et al., 2016). Highest (mantle) pressures are recorded in peripheral pyroclasts $(570 \mathrm{MPa}$ and always $>310 \mathrm{MPa}$; Fig. $5 \mathrm{c}$ ). This is in accordance with the high pressures previously documented for peripheral products emitted within the NWRZ (Bureau et al., 1998). 

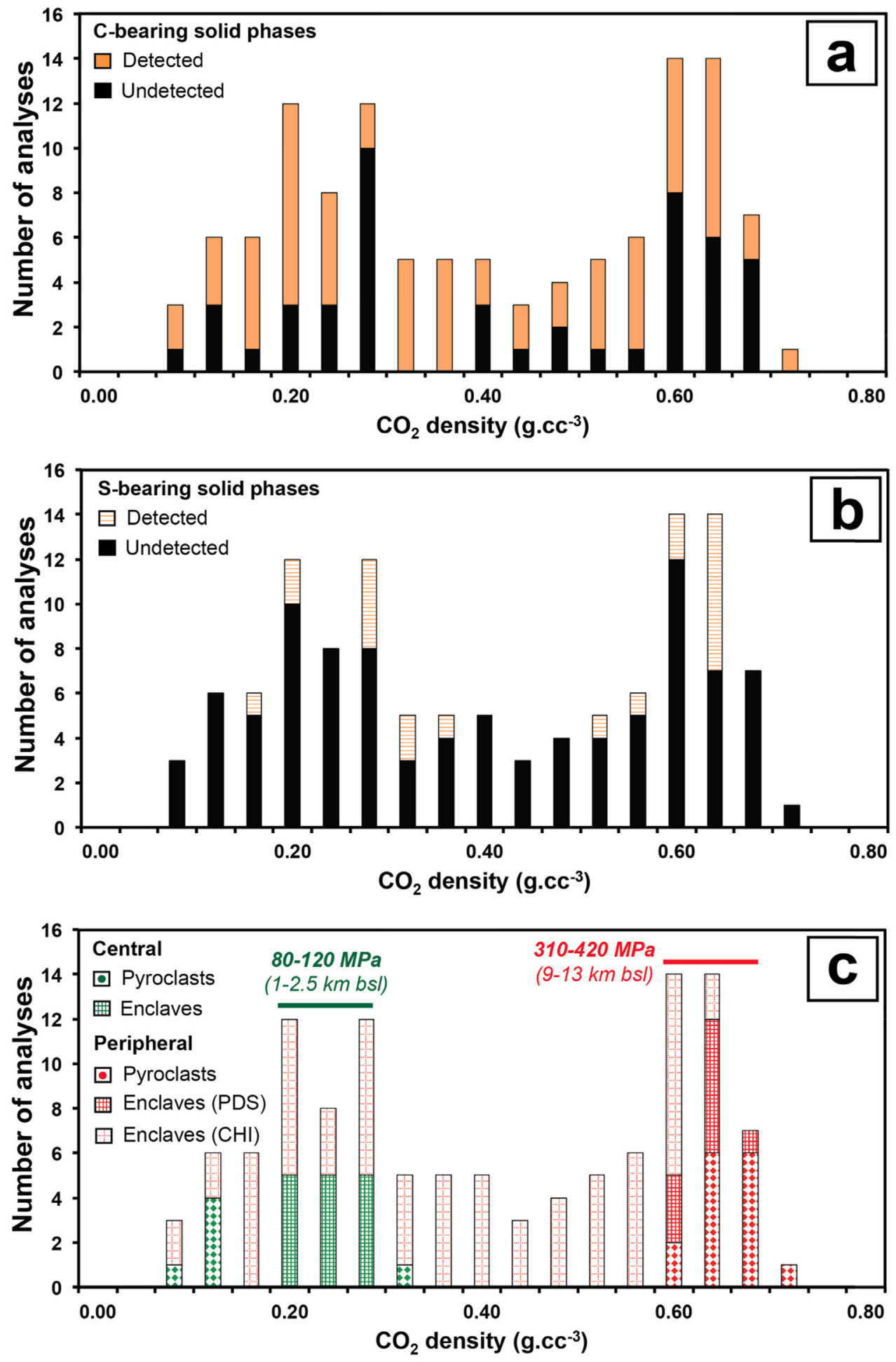

Fig. 5. Frequency distribution of $\mathrm{CO}_{2}$ densities (see text for explanations) in fluid inclusions according to (a) the presence of carbon-bearing solid phases (mainly Mg-carbonates), (b) the presence of S-bearing solid phases (mainly Mg-sulphates) and, (c) the type of sample (pyroclasts or enclaves) and its location on the volcano (central or peripheral area).

Peripheral enclaves (dunites: DUNCHI-1/2/3, PDS; wehrlites: WERCHI-1/2; harzburgite: ILR84-4) span a large range of pressures. On one hand, PDS FIs record pressures consistent with those of peripheral pyroclasts
(310-420 MPa; Fig. 5c). On the other hand, FIs from Piton Chisny enclaves span a large domain of pressure, ranging from mantle pressures (>300 MPa; ILR84-4) to crustal pressures $(<300 \mathrm{MPa}$ and mostly $<151 \mathrm{MPa})$, and thus 
overlapping the density values recorded in central products. Our large dataset allows us to define two distinct barometric modes: (1) at $80-120 \mathrm{MPa}$ that is within the volcano edifice and close to the sea level. This mode is best recorded by central products and some FIs in Piton Chisny enclaves; (2) at $310-420 \mathrm{MPa}$, that is the depth of the mantle-crust underplating layer, essentially recorded by peripheral pyroclasts, PDS enclave and part of the Piton Chisny enclaves.

Interestingly, in olivines from pyroclasts, as pressure of hosted FIs decreases, the forsterite content decreases (Fig. 6a), while calcium content increases (Fig. 6b). This positive correlation between olivine $\mathrm{Mg}$ content and pressure as well the calcium enrichment mirrors the PdF melt differentiation (dashed line in Fig. 6a and b; Di Muro et al., 2015, 2016; Boudoire, 2017). Such a compositional evolution is mainly controlled by early olivine fractionation followed by clinopyroxene (Famin et al., 2009). Central (CUM2, DUN-25M) and part of peripheral enclaves (PDS from Pas des Sables; ILR84-4 harzburgite and DUNCHI-2 from Chisny) fall on the expected trend of evolution of olivine composition with pressure. Olivines from the Chisny enclaves hosting FIs with a large range of densities have a very low $\mathrm{Ca}$ content $(<0.15 \mathrm{wt} \%$ and mostly $<0.1 \mathrm{wt} \%$ ) which does not correlate with the olivine forsterite content. This feature was previously attributed to a diffusive re-equilibration of $\mathrm{Ca}$ either in hot melts or during long residence time in the PdF plumbing system. It may thus reflect the long-lasting and potentially complex thermal history of Chisny enclaves (Brugier, 2016).

\subsubsection{Gas contents released by crystal crushing}

Interestingly, the TGC from crushed crystals from pyroclasts decreases together with pressure (dashed line in Fig. 6c). This means that for a given mineral phase, gasrich samples are preferentially trapped at greater pressures. Conversely, most of the enclaves differ from this trend, being gas-rich in spite of low recorded densities. We link this behavior to a preferential volumetric resetting of FIs in olivines from enclaves during multistage magma ascent and ponding, registering the pressure range crossed by the volcanic conduit (Supplemental Information: Appendix D). As a matter of fact, TGC in these enclaves $(<300 \mathrm{MPa}$ and mostly $<151 \mathrm{MPa})$ are similar to those in peripheral pyroclasts $(>300 \mathrm{MPa})$, suggesting a deeper storage conditions than that recorded by FI density. Partial resetting of FI densities in Chisny enclaves is also in agreement with the inferred occurrence of a dunitic-wehrlitic cumulative zone in the depth range of the underplating layer (>300 MPa; Charvis et al., 1999; Fontaine et al., 2015; Brugier, 2016; Boudoire, 2017). The highest TGC measured in the dunitic enclave from Piton Pas des Sables (PDS) and from the harzburgitic enclave from Chisny (ILR84-4) could record an even deeper origin within the upper lithospheric mantle (Fig. 6c). We point out here that crystals from enclaves are more likely to undergo diffusive re-equilibration processes (e.g., low $\mathrm{Ca}$ content, volumetric resetting of fluid inclusions) and favor the use of pressure estimations from fluid inclusions in crystals from lavas and pyroclasts in the following discussion.
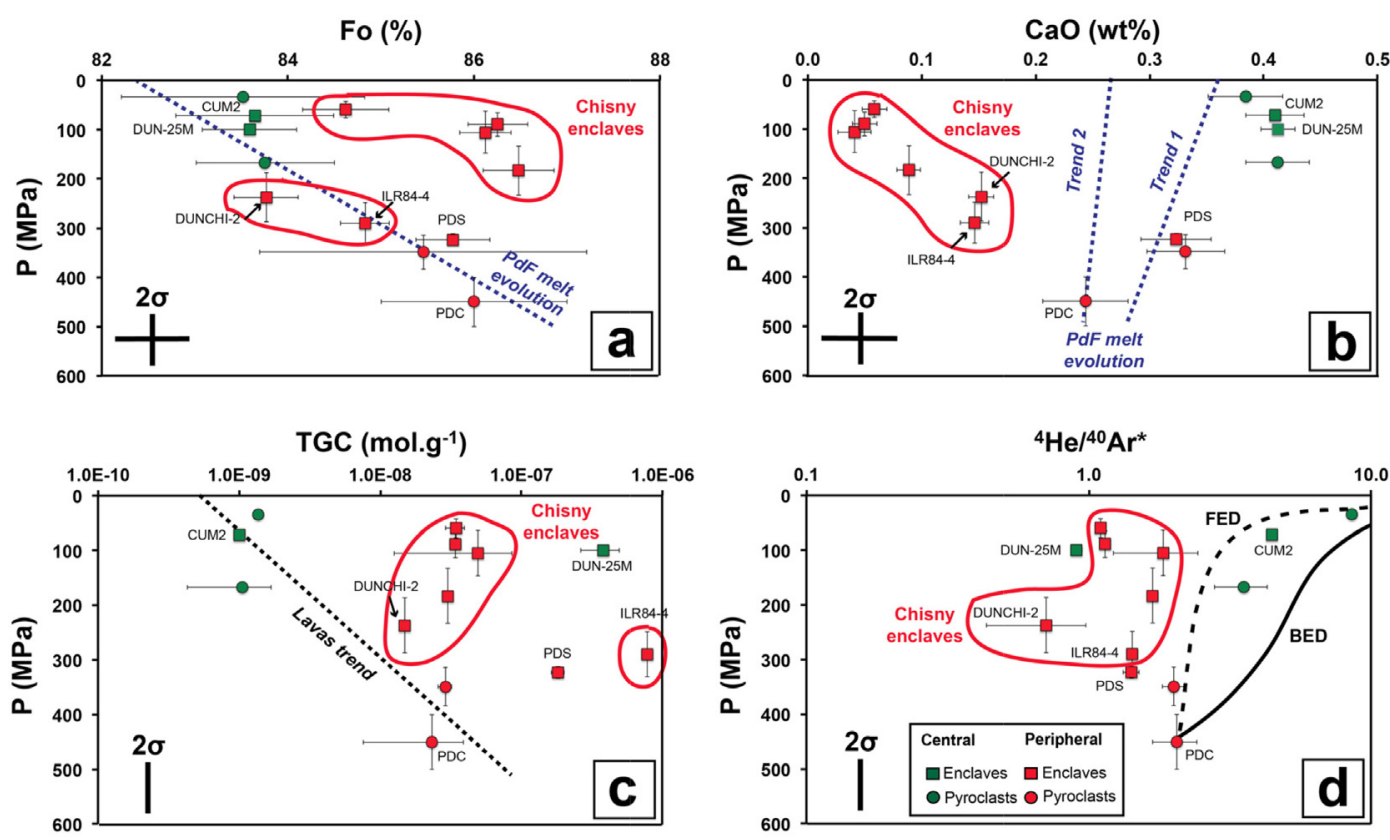

Fig. 6. Average host olivine composition (a, b) and total gas contents (TGC) or elements ratios (c, d) vs. average pressure estimations from fluid inclusion barometry. (a) Predicted olivine composition in equilibrium with PdF melt from Boudoire (2017) (b) Calcium content (wt\%) of olivines and trends from Fig. 3. (d) Fractional Equilibrium Degassing (FED) and Batch Equilibrium Degassing (BED) paths were modeled using gases solubility from Piton de Caille (PDC) melt inclusions (see text for explanation and Table 4; Iacono-Marziano et al., 2010; Duan, 2014). For each sample, the error bars represent the variability between replicates. Analytical and methodological uncertainty are also represented as $2 \sigma$ for pressure. 
If absolute gas contents may be influenced by the frequency of FIs trapped within each crystal, we expect that the ratios between noble gases are not affected. ${ }^{4} \mathrm{He} /{ }^{40} \mathrm{Ar}^{*}$ is a tracer of magmatic degassing processes due to low solubility of $\mathrm{Ar}$ in silicate melts with respect to $\mathrm{He}$ (Jambon et al., 1986; Burnard, 2004; Burnard et al., 2003, 2014; Aubaud et al., 2004; Yamamoto and Burnard, 2005; Paonita and Martelli, 2007; Iacono-Marziano et al., 2010). ${ }^{4} \mathrm{He} /{ }^{40} \mathrm{Ar}^{*}$ higher than 3.5 have been found in central pyroclasts and enclaves (CUM2), consistent with the shallow origin of these products (Fig. 6d). Conversely lower ratios $(\approx 2)$ are found in peripheral (i.e., deep) pyroclasts. In order to test this pressure-dependence of the ${ }^{4} \mathrm{He} /{ }^{40} \mathrm{Ar}^{*}$ in our products, we model batch and fractional equilibrium degassing trends (BED and FED in Fig. 6d), corresponding to closed- and open-system conditions, respectively. We start from PDC melt composition (Table 4; see explanation in the following parts), focusing on the compositional evolution of the vapor phase between $450 \mathrm{MPa}$ and $5 \mathrm{MPa}$ (Duan, 2014). This approach suggests that ${ }^{4} \mathrm{He} /{ }^{40} \mathrm{Ar}{ }^{*}$ variability between deep peripheral and shallow central products is mainly modulated by FED. Both melts degassing and differentiation are thus strongly dependent on pressure at $\mathrm{PdF}$. Low ${ }^{4} \mathrm{He} /{ }^{40} \mathrm{Ar}^{*}$ recorded by peripheral enclaves are also consistent with our previous considerations suggesting a deeper origin for these enclaves. However, these ratios are systematically lower than the rest of the dataset $(<1.9)$. Potential effects accounting for this difference will be considered and discussed in the following sections.
Nevertheless, DUN-25M is the only sample in our dataset that is not consistent with these results. In this sample, olivine composition, density of FIs, and the presence of solid or solute phases in FIs fully overlap the ranges observed in other central products (Fig. 6a and b). The TGC and ${ }^{4} \mathrm{He} /{ }^{40} \mathrm{Ar}^{*}$ are instead more in accordance with a deeper origin of this fast quenched enclave with respect to typical central products (Fig. $6 \mathrm{c}$ and d). We also point out that this sample has the largest size range of FIs described in this study (up to $100 \mu \mathrm{m}$ ) with an uncommon proportion of very large FIs (Fig. 2a) and it is the only sample collected below sea level. Our data suggests a probable volumetric resetting of FIs, leading to a strong underestimation of the entrapment pressure. However, further investigations are required to explain the processes accounting for the peculiar signature of this sample.

\subsection{Modeling of magma degassing}

\subsection{1. $\mathrm{CO}_{2}-\delta^{13} \mathrm{C}$ systematics}

Even if $\mathrm{CO}_{2}$ densities in FIs can be affected by volumetric resetting, which leads to pressure underestimation, this process does not affect the absolute $\mathrm{CO}_{2}$ contents trapped in FIs. Only $\mathrm{CO}_{2}$ leakage or sequestration in solid and liquid phases can affect the gas content released by crushing. However, we did not identify empty FIs in this study, thus limiting the effect of leakage, and we observed that liquid phases were absent or have small volume with a limited role on the $\mathrm{CO}_{2}$ sequestration. We have previously highlighted

Table 4

Starting conditions for degassing modeling. Model A: most primitive primary melt inclusion from Piton de Caille peripheral eruption (PDC; Bureau et al., 1998) and initial pressure of $570 \mathrm{MPa}$ (maximum pressure from fluid inclusions barometry). Model B: most primitive melt inclusions from Trous Blancs (TB047) peripheral eruption at $397 \mathrm{MPa}$ (maximum pressure from fluid inclusions barometry). Model C: primary melt inclusion from August 2015 central eruption at $167 \mathrm{MPa} .{ }^{*} \mathrm{CO}_{2}$ estimation based on the pressure-composition-water dependent model of Duan (2014). Temperature estimated from the hydrous-composition dependent equation of Putirka (2008). Noble gases solubility calculated from Iacono-Marziano et al. (2010). Densities estimated from Lange and Carmichael (1990). The pressure and compositional range used for the modeling fully overlap the variability described by PdF melt.

\begin{tabular}{|c|c|c|c|c|}
\hline & & $\begin{array}{l}\text { Model A } \\
\text { IR98 } 5\end{array}$ & $\begin{array}{l}\text { Model B } \\
\text { TB047-9-MI2 }\end{array}$ & $\begin{array}{l}\text { Model C } \\
\text { A2015 }\end{array}$ \\
\hline Primary melt inclusions composition (wt $\%$ ) & $\begin{array}{l}\mathrm{SiO}_{2} \\
\mathrm{TiO}_{2} \\
\mathrm{Al}_{2} \mathrm{O}_{3} \\
\mathrm{FeO}_{\mathrm{T}} \\
\mathrm{Fe}_{2} \mathrm{O}_{3} \\
\mathrm{FeO} \\
\mathrm{MnO} \\
\mathrm{MgO} \\
\mathrm{CaO} \\
\mathrm{Na}_{2} \mathrm{O} \\
\mathrm{P}_{2} \mathrm{O}_{5} \\
\mathrm{~K}_{2} \mathrm{O} \\
\mathrm{H}_{2} \mathrm{O} \\
\mathrm{CO}_{2}^{*}\end{array}$ & $\begin{array}{l}49.67 \\
2.69 \\
13.33 \\
10.03 \\
1.19 \\
8.96 \\
0.16 \\
9.97 \\
10.93 \\
2.43 \\
0.25 \\
0.55 \\
1.12 \\
0.35\end{array}$ & $\begin{array}{l}47.71 \\
2.61 \\
13.29 \\
10.62 \\
1.27 \\
9.48 \\
\\
10.90 \\
10.84 \\
2.77 \\
0.34 \\
0.92 \\
1.42 \\
0.24\end{array}$ & $\begin{array}{l}49.53 \\
2.71 \\
14.50 \\
10.03 \\
1.32 \\
8.85 \\
0.14 \\
8.12 \\
11.65 \\
2.66 \\
0.00 \\
0.65 \\
0.69 \\
0.08\end{array}$ \\
\hline Pressure $(\mathrm{MPa}) \&$ Temperature $\left({ }^{\circ} \mathrm{C}\right)$ & $\begin{array}{l}\mathrm{P} \\
\mathrm{T}\end{array}$ & $\begin{array}{l}570 \\
1257\end{array}$ & $\begin{array}{l}397 \\
1281\end{array}$ & $\begin{array}{l}167 \\
1218\end{array}$ \\
\hline Solubility (ccSTP g ${ }^{-1}$ bar $^{-1}$ ) & $\begin{array}{l}{ }^{4} \mathrm{He} \\
\mathrm{CO}_{2} \\
{ }^{40} \mathrm{Ar}^{*}\end{array}$ & $\begin{array}{l}5.23 \mathrm{E}-04 \\
3.08 \mathrm{E}-04 \\
5.16 \mathrm{E}-05\end{array}$ & $\begin{array}{l}4.58 \mathrm{E}-04 \\
3.08 \mathrm{E}-04 \\
4.46 \mathrm{E}-05\end{array}$ & $\begin{array}{l}4.81 \mathrm{E}-04 \\
2.46 \mathrm{E}-04 \\
5.16 \mathrm{E}-05\end{array}$ \\
\hline Density $\left(\mathrm{g} \mathrm{cc}^{-1}\right)$ & $\mathrm{d}$ & 2.72 & 2.69 & 2.68 \\
\hline
\end{tabular}


that the TGC is more prone to reflect the original pressure of crystallization. Similar conclusion can be attained for the $\mathrm{CO}_{2}$ content released by crushing, considering that $\mathrm{CO}_{2}$ contributes to more than $95 \%$ of the TGC (Table 2).

To constrain degassing processes and extents, it is a common approach to evaluate how $\mathrm{CO}_{2}$ concentration dissolved in glasses or trapped in vesicles varies respect to the $\delta^{13} \mathrm{C}$ signature (Macpherson and Mattey, 1994; Shaw et al., 2004; Aubaud et al., 2005, 2006; Barry et al., 2014). Here we investigate the evolution of $\mathrm{CO}_{2}$ content and related carbon isotopic signature by assuming that the evolution of the $\mathrm{CO}_{2}$ content trapped by fluid inclusions in crystals is positively correlated with the $\mathrm{CO}_{2}$ content dissolved in the melt. This assumption is supported by the pressure-TGC and pressure-Fo correlations described by the crystals we analysed in pyroclasts (Fig. 6): the deeper (higher pressure) and more magnesian (high Fo) is the basaltic melt, the larger is the amount of $\mathrm{CO}_{2}$ (e.g., TGC) released by crystal crushing (Fig. 6). Similarly, dissolved $\mathrm{CO}_{2}$ content increases with increasing pressure and magnesium content in basaltic melts (Aubaud et al., 2004; Papale et al., 2006).

To model magma degassing and the isotopic composition of the vapour phase, we have taken into account the carbon isotope fractionation factor between vapour and melt $\left(\Delta=\delta^{13} C_{\text {melt }}-\delta^{13} C_{\text {vapor }}\right.$ ) in order to modify the initial BED and FED degassing equations of Macpherson and Mattey (1994) available for the melt phase:

$\delta^{v}=\delta^{p}-\Delta \times\left(\frac{C_{B E D}^{r}}{C^{p}}\right)$ for batch equilibrium degassing model

and

$\delta^{v}=\delta^{p}+\Delta \times\left(\ln \left(\frac{C_{F E D}^{r}}{C^{p}}\right)-1\right)$

for fractional equilibrium degassing model

where BED and FED subscript refers to batch equilibrium degassing and fractional equilibrium degassing model, respectively, $\delta^{v}$ represent the isotope composition $\left(\delta^{13} \mathrm{C}\right)$ of the $\mathrm{CO}_{2}$ in the vapor phase (i.e., trapped by FIs), $C^{r}$ is the $\mathrm{CO}_{2}$ contents from crushed crystals (here considered as a proxy of the $\mathrm{CO}_{2}$ contents dissolved in melt), $C^{p}$ and $\delta^{p}$ are the initial concentrations and isotope compositions of the exsolved phase of $\mathrm{CO}_{2}$ that should be released by fluid inclusions during crystal crushing, and $\Delta=\delta^{13} C_{\text {melt }}-\delta^{13} C_{\text {vapor }}$.

A melt-vapor fractionation factor $(\Delta)$ of $+2.2 \pm 0.2$ and the uncertainty related to the analytical procedure were determined from Eq. (3) (see below) by calculating the slope of the best fit regression line through the analysis of the sample with the highest gas content (ILR84-4) (a) and PDC (b), which are best fitted by a FED equation (Barry et al., 2014):

$\Delta=\frac{\left(\delta_{b}^{v}-\delta_{a}^{v}\right)}{\ln \left(\frac{C_{b}^{r}}{C_{a}^{r}}\right)}$

The factor of melt-vapor fractionation we estimate falls in the range of experimental data and values obtained for other volcanoes $(+1.8$ to +4.5 ; Javoy et al., 1978; Mattey,
1991; Aubaud et al., 2005); moreover, our $\Delta$ is close to the value assumed at Mount Etna and Stromboli for similar modeling $(\Delta=+3$; Paonita et al., 2012; Gennaro et al., 2017).

Then, considering that one $\delta^{v}$ value may correspond to one $C_{B E D}^{r}$ and one $C_{F E D}^{r}$, it is possible to combine the Eqs. (1) and (2) in order to obtain $C^{p}$ :

$\ln \left(C^{p}\right)-\frac{C_{B E D}^{r}}{C^{p}}=\ln \left(C_{F E D}^{r}\right)-1$

Using two samples (ILR84-4 and PDS) following a BED trajectory (here based on PDS that is the only enclave sample that does not present re-equilibration effects, neither the presence of carbonates in fluid inclusions; Supplemental Information: Appendix B; Fig. 6), we finally obtain from (4):

$C^{p}=\frac{\left(C_{B E D}^{I L R 84-4}-C_{B E D}^{P D S}\right)}{\ln \left(C_{F E D}^{I L R 4-4}-C_{F E D}^{P D S}\right)}$

where $C_{B E D}^{I L R 84-4, P D S}$ are the $\mathrm{CO}_{2}$ contents measured by crystal crushing and $C_{F E D}^{I L R 84-4, P D S}$ the calculated values using the best fit regression line considered to represent the FED trajectory. Using the obtained values for $C^{p}, \triangle, C_{B E D}^{I L R 84-4, P D S}$, $C_{F E D}^{I L R 44, P D S}$ and $\delta^{a, b}$, the Eqs. (1) and (2) lead to $\delta^{p}=$ $-0.8 \pm 1.0 \%$ considering the average and the uncertainty related to both the analytical procedure and the natural variability of the samples (see Barry et al. (2014)). Using the melt-vapor fractionation factor, it leads to an initial $\delta^{13} \mathrm{C}_{\text {melt }}=-3.0 \pm 1.2 \%$ at $\mathrm{PdF}$. This estimation is fully consistent with values reported for other hotspots $(-3.4$ to $-4 \%$ at Kilauea; Gerlach and Taylor, 1990; -3 to $-4 \%$ for Society Islands; Aubaud et al., 2005; Deines, 2002) as well as for very little degassed popping rocks from mid-Atlantic ridge (-3.7\%o; Javoy and Pineau, 1991; Michael and Graham, 2015).

Using these calculated parameters, our whole dataset is well-fitted by the range of BED and FED degassing paths modeled from the starting conditions defined above (Model 1; Fig. 7a). PDC products (peripheral pyroclasts) are closer to a FED path. Other data (mostly related to enclaves) lie between FED and BED trajectories. Commonly such a behavior is interpreted as related to different stages of degassing (Cartigny et al., 2001, Sarda and Moreira, 2002, Shaw et al., 2004). However, other processes may account for the $\delta^{13} \mathrm{C}$ variability as (1) source variability (Deines, 2002), (2) assimilation of a crustal component (Parks et al., 2013) and/or, (3) calcite precipitation (Ray et al., 2009; Dubacq et al., 2012; Paonita et al., 2012; Barry et al., 2014). At PdF, it has been inferred that source variability (1) and contamination (2) play only a minor role in the melt geochemistry and cannot account for the observed variability in bulk rock composition [see Vlastelic and Pietruzska (2016) for a review]. Nevertheless, we have also seen that carbonates are systematically present in our FIs (3). Carbon isotope fractionation due to calcite precipitation is highly temperature-dependent (Bottinga, 1969; Hoefs, 2015) inducing a ${ }^{13} \mathrm{C}$-enrichment in the residual vapour phase at temperature higher than $192^{\circ} \mathrm{C}$. Assuming that about $10 \%$ of the initial $\mathrm{CO}_{2}$ could precipitate as carbonate (Bolder-Schrijver et al., 2000) we estimate 

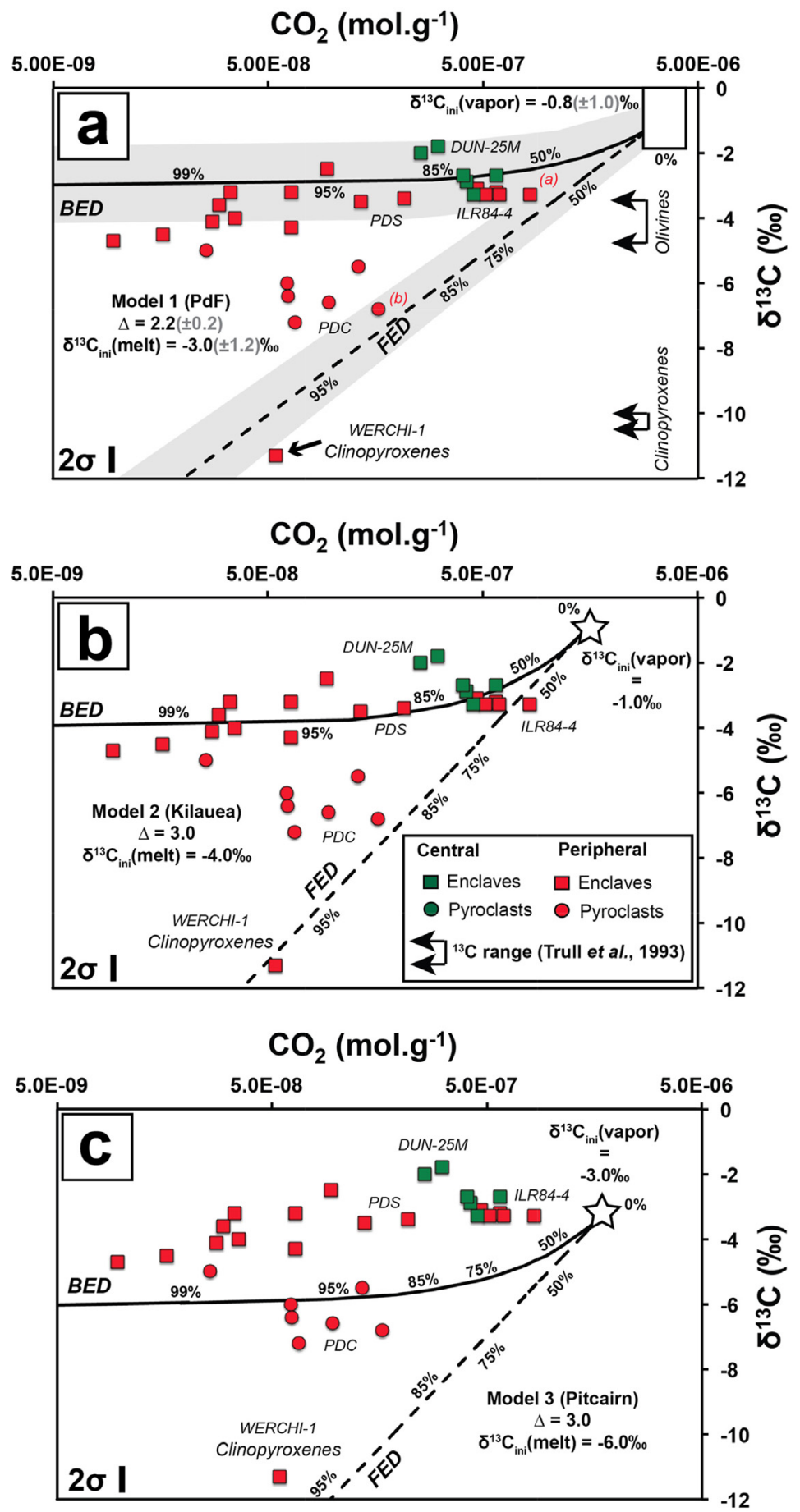

Fig. 7. $\mathrm{CO}_{2}$ contents vs. $\delta^{13} \mathrm{C}$ from crushed minerals. Batch Equilibrium Degassing (BED) and Fractional Equilibrium Degassing (FED) are modeled with three different starting conditions ( $\mathrm{a}, \mathrm{b}, \mathrm{c})$. The extent of degassing $(0-50-75-85-95-99 \%)$ is reported along the curves. (a) Fractionation factor $(\Delta=2.2 \pm 0.2)$ and initial melt $\delta^{13} \mathrm{C}(=-3.0 \pm 1.2 \%)$ computed from the best fit on PdF products and taking into account the uncertainties related to the analytical and natural variability (see text for explanation; Barry et al., 2014). Grey field highlights the expected range of BED and FED considering the uncertainty related to the starting conditions $\left(\Delta\right.$ and $\left.\delta^{13} \mathrm{C}\right)$. (b) Fractionation factor $(\Delta=3)$ corresponding to the average reported in the literature (see text for explanations) and to an initial melt $\delta^{13} \mathrm{C}(=-4 \%$ ) for Kilauea hotspot (Gerlach and Taylor, 1990). (c) Fractionation factor $(\Delta=3)$ corresponding to the average reported in the literature (see text for explanations) and to a primitive melt $\delta^{13} \mathrm{C}(=-6 \%)$ for Pitcairn hotspot (Aubaud et al., 2006). $\delta^{13} \mathrm{C}$ range from -4 to $-6 \%$ is considered to overlap the mantle variability (Cartigny et al., 2001). Black arrows correspond to the $\delta^{13} \mathrm{C}$ variability obtained by step-heating olivines and clinopyroxenes from Piton Chisny peripheral enclaves and determined by Trull et al. (1993). 
a maximum variation from $-1 \%$ o to $+0.3 \%$ (between 25 and $1000{ }^{\circ} \mathrm{C}$; Hoefs, 2015) that is broadly overlapped by the uncertainty related to the method of FIs extraction and by the natural variability for a same sample (Table 3 ). Such process may be sufficient to explain the few high $\delta^{13} \mathrm{C}$ values in DUN-25M (Fig. 7a), but cannot be considered as a major process influencing our dataset.

In order to compare our result with a more classical approach, we modeled BED and FED paths with parameters constrained for other well-known hotspots environments: (1) Model 2 (Fig. 7b) refers to Kilauea starting conditions with an initial $\delta^{13} \mathrm{C}_{\text {melt }}=-4 \%$ o that is the lowest estimation made by Gerlach and Taylor (1990); (2) Model 3 (Fig. 7c) refers to Pitcairn starting conditions with an initial $\delta^{13} \mathrm{C}_{\text {melt }}=-6 \%$ (Aubaud et al., 2006). In both models we assumed a melt-vapor fractionation factor $\Delta=+3$ in accordance with the average from literature and close to our estimation for Piton de la Fournaise (Javoy et al., 1978; Mattey, 1991; Aubaud et al., 2006). With these models, we fully overlap the variability of starting conditions for hotspots (Barry et al., 2014). In fact, there is a good consistency between our model for PdF (Model 1) and the Kilauea model (Model 2). Conversely, BED and FED trajectories predicted from the Pitcairn model (Model 3) does not fit our data, most of them lying above the BED trajectory, even above the starting conditions for some of them (Fig. 7c) that make this model unrealistic for PdF.

Therefore, in our case, we stress that (1) $\delta^{13} \mathrm{C}$ variability observed in our dataset is consistent with different stages of degassing and (2) estimated starting conditions are fully in accordance with values reported at Hawaii in a similar geodynamic context. It is important to note that if the modeling proposed in Model 1 (Fig. 7a) is linked to the amount of $\mathrm{CO}_{2}$ released by crushing instead of the amount of $\mathrm{CO}_{2}$ dissolved in the melt, it cannot in any way affect the interpretation of the $\delta^{13} \mathrm{C}$ signature. For instance, the $\delta^{13} \mathrm{C}$ signature of PDC $(-6.4 \pm 0.5 \%)$ can only be reached by a FED trajectory and highlights an important extent of degassing with respect to the source $(90 \pm 7 \mathrm{wt} \%)$ whatever is the initial $\mathrm{CO}_{2}$ content assumed for modeling FED and BED trajectories.

\subsection{2. $\mathrm{He}-\mathrm{Ar}-\mathrm{CO}_{2}$ systematics}

We report that olivine crystal composition $(\mathrm{Fo} ; \mathrm{Ca})$ and extracted gas content from PdF pyroclasts are consistently record melt differentiation and degassing at variable depths in the volcano plumbing system. Enclaves exhibit a more complex signature, which could result from a combination of both magma degassing and re-equilibration processes during ponding and long-lasting residence at depth. Actually, even if $\mathrm{CO}_{2}$ content is not significantly affected by diffusion across the host crystals, diffusive fractionation could affect the variability of other gaseous species trapped in FIs like $\mathrm{H}_{2} \mathrm{O}$ and noble gases (Danyushevsky et al., 2002; Burnard, 2004; Yamamoto et al., 2009). We will now investigate the processes affecting $\mathrm{He}, \mathrm{Ar}$ and $\mathrm{CO}_{2}$ contents released by crystal crushing.

We first consider our data in terms of classical modeling of magmatic degassing, controlling noble gas and $\mathrm{CO}_{2}$ ratios. Actually, ${ }^{4} \mathrm{He} / \mathrm{CO}_{2}$ and ${ }^{4} \mathrm{He} /{ }^{40} \mathrm{Ar}^{*}$ bring important information on magmatic degassing process (e.g., Burnard, 2004; Burnard et al., 2003, 2014; Paonita et al., 2012; Barry et al., 2014; Correale et al., 2014). The degassing trends potentially recorded in the vapour phase

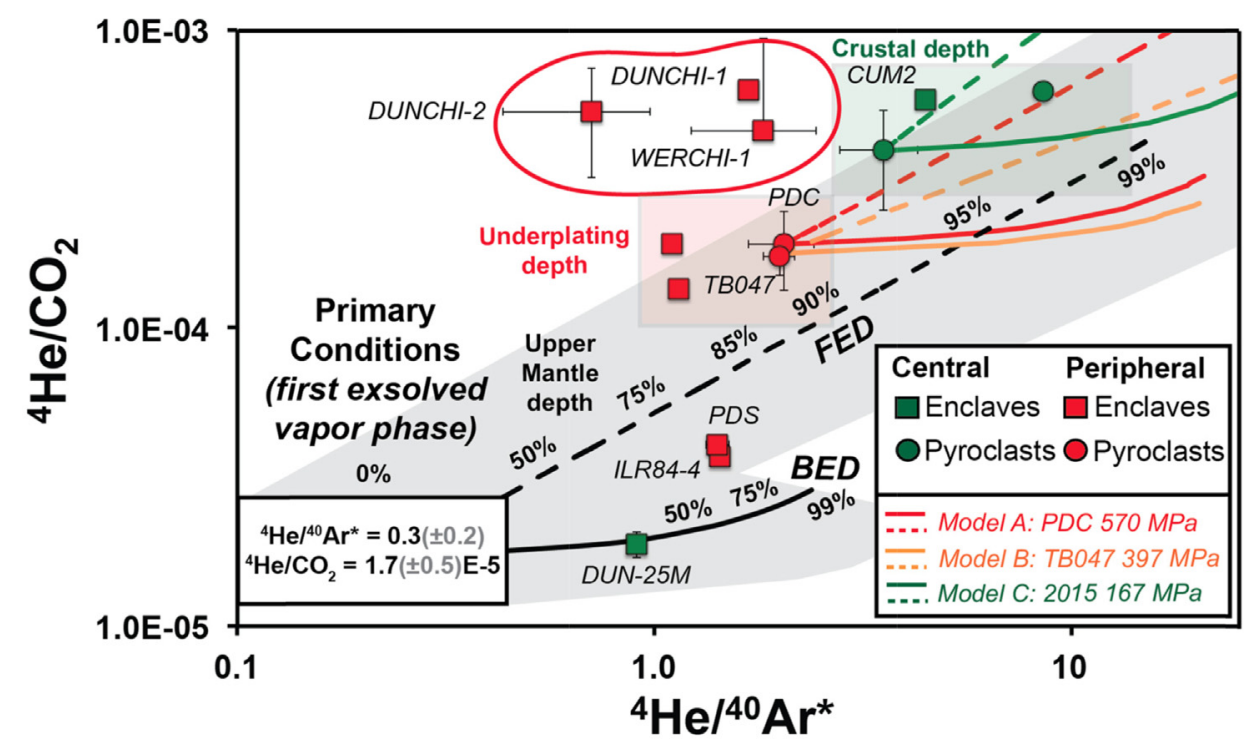

Fig. 8. Modeling of ${ }^{4} \mathrm{He} /{ }^{40} \mathrm{Ar}^{*}$ vs. ${ }^{4} \mathrm{He} / \mathrm{CO}_{2}$ in the fluid phase following Fractional Equilibrium Degassing (FED) and Batch Equilibrium Degassing (BED) paths. The extents of degassing (0-50-75-85-95-99\%) are reported along the curves. Primary conditions are calculated assuming that PDC has undergone $89 \%$ of open-system degassing with respect to primary melts as suggested by the $\delta^{13} \mathrm{C}$ analysis in this study. Starting conditions used for Models A-B-C are defined in Table 4 (see text for explanations). Enclaves deviating from equilibrium degassing paths are identified (red contour line). Color filled areas correspond to specific trapping depth ranges and relative position in the magmatic plumbing system of PdF. Grey field highlights the expected range of BED and FED considering the uncertainty related to the starting conditions $\left({ }^{4} \mathrm{He} /{ }^{40} \mathrm{Ar}^{*}\right.$ and ${ }^{4} \mathrm{He} / \mathrm{CO}_{2}$ ). (For interpretation of the references to color in this figure legend, the reader is referred to the web version of this article.) 
extracted from the melt were modeled using the BED and FED equations (Fig. 8; Jambon et al., 1986; Shaw et al., 2004, Hoefs, 2015). We constrain starting conditions by taking into account (1) the ${ }^{4} \mathrm{He} /{ }^{40} \mathrm{Ar}^{*}$ measured in PDC products $(2.05 \pm 0.37)$, (2) that PDC products suffered 90 $\pm 7 \mathrm{wt} \%$ of FED as suggested by the $\delta^{13} \mathrm{C}$ study, (3) ArHe solubility $\left(\mathrm{S}_{\mathrm{He}} / \mathrm{S}_{\mathrm{Ar}}=10\right)$ from representative melt inclusion composition from PDC olivines (Bureau et al., 1998; Table 4). In the case of $\mathrm{S}_{\mathrm{He} /} \mathrm{S}_{\mathrm{Ar}}$, we assume the linearity of Ar-He solubility up to $5 \mathrm{GPa}$ (Sarda and Guillot, 2005), i.e. compatible with source melting conditions for La Réunion hotspot (partial melt production at $4 \mathrm{GPa}$; Fretzdorff and Haase, 2002). Consequently, we have calculated that the first exsolved vapour phase has an initial ${ }^{4} \mathrm{He} /{ }^{40} \mathrm{Ar}^{*}$ of $0.3 \pm 0.2$ (Fig. 8). Having in mind that the typical production ratio in the mantle is 2-5 (Marty, 2012) and that $\mathrm{S}_{\mathrm{He}} \mathrm{S}_{\mathrm{Ar}}=10$ (Poreda and Farley, 1992; Matsuda and Marty, 1995; Iacono-Marziano et al., 2010; Tedesco et al., 2010; Marty, 2012), our estimated ratio is within the range expected for the first degassing vapour $\left({ }^{4} \mathrm{He} /{ }^{40} \mathrm{Ar}=0.2-0.5\right)$. Our carbon study has suggested an initial $\delta^{13} \mathrm{C}$ of $-0.8 \pm 1.0 \%$ in the first exsolved fluid phase and a potential maximum $\mathrm{CO}_{2}$ content of $3.6 \pm 0.7 \times 10^{-6}$ $\mathrm{mol} \mathrm{g}^{-1}$ from the crushing procedure (Fig. 7a). Using the fitting power function from Fig. $4 \mathrm{~b}$, we estimate a corresponding initial ${ }^{4} \mathrm{He}$ content of $6.2 \pm 0.7 \times 10^{-11} \mathrm{~mol} \mathrm{~g}^{-1}$ and thus an initial ${ }^{4} \mathrm{He} / \mathrm{CO}_{2}$ of $1.7 \pm 0.5 \times 10^{-5}$.

${ }^{4} \mathrm{He} /{ }^{40} \mathrm{Ar}^{*}$ vs. ${ }^{4} \mathrm{He} / \mathrm{CO}_{2}$ degassing trends suggest that FED is predominant in the evolution from the source to deep magmas feeding peripheral eruption to shallow magmas producing the central activity (Fig. 8). Conversely, the data of some enclaves (PDS, ILR84-4, DUN-25M) lie between FED and BED trajectories. These modeling paths are fully consistent with those predicted by the $\delta^{13} \mathrm{C}$ (Fig. 7). Deviations from these degassing trends are mainly observed in Piton Chisny enclaves (DUNCHI-1, DUNCHI-2 and WERCHI-1), characterized by apparently higher ${ }^{4} \mathrm{He} / \mathrm{CO}_{2}$ or lower ${ }^{4} \mathrm{He} /{ }^{40} \mathrm{Ar}^{*}$ (Fig. 8).

Noble gases and $\mathrm{CO}_{2}$ contents in the vapour phase are dependent on their initial abundance, diffusivity and solubility in melts (Carroll and Stolper, 1991, 1993; Shibata et al., 1996, 1998; Chamorro-Perez et al., 1996, 1998; Paonita et al., 2000; Schmidt and Keppler, 2002; Miyazaki et al., 2004; Marrocchi and Toplis, 2005; Paonita, 2005 and references therein; Bouhifd and Jephcoat, 2006; Gonnermann and Mukhopadhyay, 2007; Iacono-Marziano et al., 2010; Shishkina et al., 2014). $\mathrm{CO}_{2}$ and Ar diffusivities in basaltic melts are similar, while that of $\mathrm{He}$ is 100 times higher (Gonnermann and Mukhopadhyay, 2007). In case of disequilibrium degassing, we would expect a similar enrichment in $\mathrm{Ar}$ and $\mathrm{CO}_{2}$ of the vapour phase but a more extensive enrichment in $\mathrm{He}$, and that is not observed in our samples (Fig. 4). In our dataset, only DUNCHI-1 could be the result of disequilibrium degassing, however this process would imply a fast degassing dynamics. We argue that DUNCHI-1 is a cumulate that should have been formed from melts ponding during long periods, a process that should favor equilibrium degassing. Therefore, we exclude disequilibrium degassing or it has a restricted role in the interpretation of our dataset.
Gas solubility in silicate melt is affected by numerous factors, as temperature, pressure, oxygen fugacity and melt composition. At PdF, the (slight) compositional variability of both peripheral and central melts was mainly attributed to crystallization-assimilation processes and only subordinately to source heterogeneities (see Vlastelic and Pietruzska (2016) for a review). In order to cover the variability of PdF melts in terms of chemical composition and pressure-temperature domains, we have tested three different models based on different initial melt inclusion compositions (corrected from post-trapping effects; Boudoire, 2017). Melt inclusions were measured in olivines extracted from the same products analysed for noble gases in this study (Table 4; Bureau et al., 1998). In order to model magma degassing, we choose the maximum pressure recorded in the FIs of three distinct eruptive products as starting pressure for each model. Similarly, Viti and Frezzotti (2000) suggest that the maximum pressure estimated from FIs is more likely to provide a reliable estimation of the crystallization depth. Model A: based on melt inclusions in olivines from the peripheral PDC eruptive site, with a starting pressure of $570 \mathrm{MPa}$. Model $\mathrm{B}$ : based on melt inclusions in olivines from the peripheral Trous Blancs (TB047) eruptive site, with an initial pressure of $397 \mathrm{MPa}$. Model C: based on melt inclusions from the central August 2015 (REU151026-1a) eruption and a starting pressure of $167 \mathrm{MPa}$. These three models cover a large range of pressure (167-570 $\mathrm{MPa})$, temperature $\left(1218-1281^{\circ} \mathrm{C}\right.$; from the hydrous-composition dependent equation of Putirka (2008)), and melt compositions (MgO: 8.1-10.9 wt $\% ; \mathrm{K}_{2} \mathrm{O}$ : $\left.0.5-0.9 \mathrm{wt}^{\mathrm{O}} \% ; \mathrm{SiO}_{2}: 47.7-49.7 \mathrm{wt} \% ; \mathrm{H}_{2} \mathrm{O}: 0.7-1.4 \mathrm{wt} \%\right)$. They broadly overlap the geochemical variability of PdF melts in both major, traces and isotope signature in the whole volcano plumbing system (Valer, 2016). Noble gases and $\mathrm{CO}_{2}$ solubility were calculated using experimental results (e.g., Iacono-Marziano et al., 2010; Duan, 2014 and references therein), well adapted for this compositional and pressuretemperature range, and are thus representative of the range of solubility expected for PdF melts. These calculations show that solubility in all studied melts decreases from $\mathrm{He}$ to $\mathrm{CO}_{2}$ to $\operatorname{Ar}$ (Table 4; e.g., Iacono-Marziano et al., 2010; Paonita et al., 2012 and references therein).

Interestingly, the degassing trends indicate no major difference between the three models (Fig. 8) suggesting that melt composition, temperature and pressure variability play the a minor role in the evolution of $\mathrm{He}-\mathrm{Ar}-\mathrm{CO}_{2}$ ratios by degassing at PdF. For instance, Model A-B-C present a very similar behavior in spite of (1) almost $400 \mathrm{MPa}$ of pressure change and, (2) geochemical variability in melt composition spanning the full range reported for $\mathrm{PdF}$ (Table 4; Valer, 2016). This suggests that the deviations from the predicted degassing trends recorded by Piton Chisny enclaves (DUNCHI-1, DUNCHI-2 and WERCHI-1) reveal the occurrence of processes other than the geochemical variability of PdF magmas. Actually, we have documented that these products (1) fall out of the $95 \%$-confidence interval of the gas fitting equations (Fig. 4), (2) generally record a shallower pressure mode than other peripheral products (Fig. 5c) and, (3) present a distinct petrological signature (Fig. 6b). This could 
highlight an older/distinct magmatic history with respect to other samples analysed in this study (Matsuda and Marty, 1995; Burnard, 2004; Gautheron et al., 2005; Yamamoto et al., 2009).

\subsection{The architecture of the magmatic plumbing system beneath Piton de la Fournaise}

Deciphering deep degassing in volcanic systems is challenging and is generally based on experimental results and modeling. At PdF, we have based our study on a multiparametric approach coupling barometric data, olivine composition, melt and fluid inclusion chemistry, noble gases, $\mathrm{CO}_{2}$, and carbon isotopes systematic. Consistently with previous studies, our result confirm that central (intracaldera) eruptions emit evolved and degassed melts stored at shallow crustal levels, whereas the products of peripheral eruptions are more primitive, gas-richer and record the signature of deeper levels, whose pressure fits with that of the mantlecrust underplating layer or even higher depth (see Di Muro et al., 2016 for a review). Peripheral enclaves (PDS and ILR84-4) testify of the deepest origin (upper lithospheric mantle) in our dataset.

Based on these results, we put new constrains on the plumbing system and magma degassing at PdF. PDC peripheral pyroclasts is the sample for which the largest dataset is available (Bureau et al., 1998; Welsch et al., 2013). By using melt inclusions composition (Table 4) with $1.1 \mathrm{wt} \%$ of dissolved $\mathrm{H}_{2} \mathrm{O}$ (measured in the PDC melt inclusion and close to the primary melt estimation of Bureau et al. (1998) and Di Muro et al. (2014)), $\mathrm{H}_{2} \mathrm{O}-\mathrm{CO}_{2}$ saturation pressure modeling (Duan, 2014) predicts that $0.35 \mathrm{wt} \%$ of $\mathrm{CO}_{2}$ is dissolved in the melt at $570 \mathrm{MPa}$ (maximum pressure from fluid inclusions barometry; Table 1). Our study suggests that this pressure is representative of the crystallization depth. The calculated amount of dissolved $\mathrm{CO}_{2}$ is fully in accordance with results from other $\mathrm{H}_{2} \mathrm{O}-\mathrm{CO}_{2}$ saturation models (Papale et al., 2006), and is very similar to the mean estimation of $0.30 \mathrm{wt} \%$ of $\mathrm{CO}_{2}$ in MORB-like undegassed magmas and in the mantle (Gale et al., 2013; Michael and Graham, 2015). This value is higher than the maximum concentration of dissolved $\mathrm{CO}_{2}$ measured in PDC melt inclusions by FTIR (i.e., $0.18 \mathrm{wt} \%$; $280 \mathrm{MPa}$; Bureau et al.,
1998; Di Muro et al., 2016). However, many post-trapping process may affect the $\mathrm{CO}_{2}$ estimation in melt inclusions (Wallace et al., 2015; Maclennan, 2017). In fact, Maclennan (2017) has recently shown that most of the estimated $\mathrm{H}_{2} \mathrm{O}-\mathrm{CO}_{2}$ saturation pressures reflect extensive decrepitation of melt inclusions during melt ascent (when the differential pressure between the melt inclusion and the external environment is higher than $250 \mathrm{MPa}$ ). An amount of $\mathrm{CO}_{2}$ dissolved in PDC melt of about $0.35 \mathrm{wt} \%$ is thus a reliable assumption. Based on these starting conditions and on the predominant role of fractional equilibrium degassing (FED) in our dataset, we estimate that (Table 5):

(1) The primary melt formed at $4 \mathrm{GPa}$ has up to $3.5 \pm 1.4 \mathrm{wt} \%$ of dissolved $\mathrm{CO}_{2}$ and the first exsolved vapor phase an initial ${ }^{4} \mathrm{He} /{ }^{40} \mathrm{Ar}^{*}$ of $0.3 \pm 0.2$ (considering the $90 \pm 7 \%$ of FED degassing suggested for PDC on Figs. 7 and 8). The initial $\mathrm{CO}_{2}$ content is much higher than previous estimation made by Bureau et al. (1998) at PdF (1.0 wt\%) based on melt inclusions $\mathrm{H}_{2} \mathrm{O}-\mathrm{CO}_{2}$ saturation pressure modeling (Table 5) predicts pressure higher than $3 \mathrm{GPa}$ (limit of the model; Duan, 2014), in agreement with the depth of partial melt extraction from the mantle source beneath PdF (ca. $4 \mathrm{GPa}$; Fretzdorff and Haase, 2002),

(2) The parental melt triggering the crystallization of our most primitive sample (ILR84-4 harzburgite) could have an amount of dissolved $\mathrm{CO}_{2}$ of $1.1 \pm 0.9 \mathrm{wt} \%$ (average between BED and FED trajectories for ILR84-4 on Figs. 7 and 8), fully consistent with previous estimations made by Bureau et al. (1998) at $\mathrm{PdF}(1.0 \mathrm{wt} \%)$. In the fluids related to this primitive magma, the ${ }^{4} \mathrm{He} /{ }^{40} \mathrm{Ar} *$ should be about $0.8 \pm 0.6$. Based on $\mathrm{CO}_{2}-\mathrm{H}_{2} \mathrm{O}$ saturation pressures modeling (Duan, 2014), we estimate that the parental melt that formed ILR84-4 ponded at pressures close to $1 \mathrm{GPa}$ (Table 5). This pressure is consistent with the deep melt horizon identified beneath La Réunion Island by seismic studies (Gallart et al., 1999; Massin, 2009; Fontaine et al., 2015), stress-modeling (Gerbault et al., 2017) and petrological models (Albarède et al., 1997; Fretzdorff and Haase, 2002).

Table 5

Reconstruction of initial gas composition and conditions (in bold) for distinct PdF products representative of different levels of the plumbing system (taking into account the analytical uncertainty and the variability of the analysis). (1) Estimation of the degassing extent from the initial $\delta^{13} \mathrm{C}$ calculated in this study (from $-4.2 \%$ to $-1.8 \%$ considering all uncertainties during the modeling). (2) Estimation of initial $\mathrm{CO}_{2}$ content is obtained from the degassing extent for an initial $0.35 \mathrm{wt} \% \mathrm{CO}_{2}$ dissolved content in Piton de Caille melt inclusion at $5.7 \mathrm{kbar}$ (maximum pressure) (3) Estimation of the saturation pressure of $\mathrm{CO}_{2}-\mathrm{H}_{2} \mathrm{O}$ (Duan, 2014) based on the inferred composition of the PdF primary melt (Fretzdorff and Haase, 2002). (4) Recalculation of the initial ${ }^{4} \mathrm{He}^{40} \mathrm{Ar}^{*}$. (5) Estimation of $\delta^{13} \mathrm{C}$ values in central products.

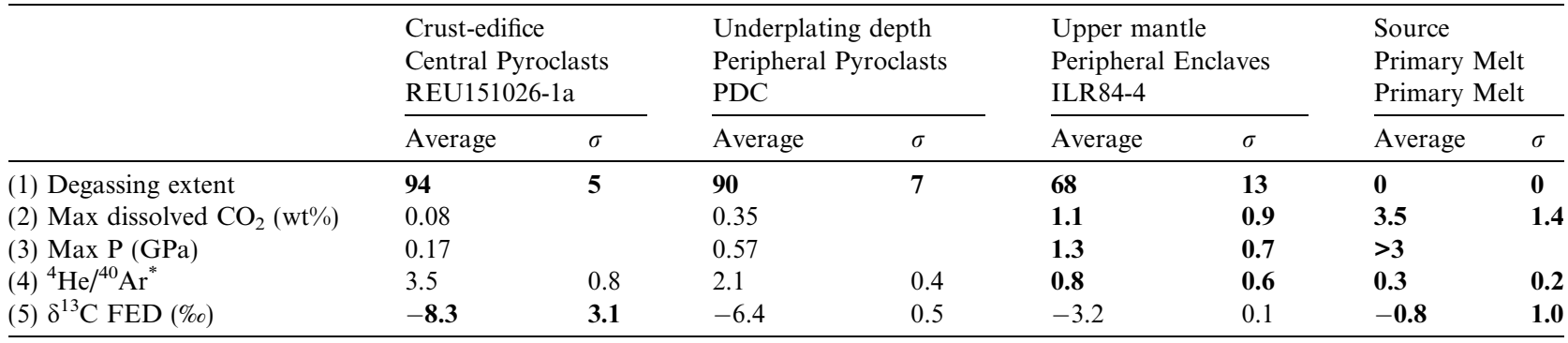


(3) The low $\mathrm{CO}_{2}$ content of olivine from central pyroclasts hinders the measurement of $\delta^{13} \mathrm{C}$ by crystal crushing. The open-degassing paths suggested by noble gases ratios from FIs of PDC olivines and central products (Figs. 5 and 7) argue for at least $94 \pm 5 \%$ of deep degassing for these products with respect to the primary melt. Starting from the $\delta^{13} \mathrm{C}$ of the initial vapor phase calculated in this study $(-0.8 \pm 1.0 \%)$, we consequently estimate that the $\delta^{13} \mathrm{C}$ of the central products (here based on the August 2015 eruption: REU151026-1a) could be as low as $-8.3 \pm 3.1 \%$ just following an opendegassing path $(94 \pm 5 \%$; FED). These estimations are more negative than $\delta^{13} \mathrm{C}$ measurements performed by Marty et al. (1992) in summit fumaroles of $\operatorname{PdF}(-4.1 \%)$ and in the thermal springs located on PdN volcano ( $-4.7 \%$; Cilaos in Fig. 1; $30 \mathrm{~km}$-far from the PdF summit), during a quiescent period 25 yrs ago. However, magmatic dynamics could have changed between 1992 and 2015, especially after the 2007 caldera-collapse eruption. Actually, fumaroles sampled by Marty et al. (1992) are not accessible anymore, while current analysis (2016-2017) in gases from Cilaos thermal springs indicate lower $\delta^{13} \mathrm{C}$ values (around $-6 \%$; OVPF database) than fumaroles and thermal springs collected by Marty et al. (1992).

\subsection{Implications on the extensive degassing in the upper mantle beneath Piton de la Fournaise}

Regarding these new results, we now propose a model of magma degassing from mantle partial melting up to the crustal plumbing system feeding the activity of PdF volcano (Fig. 9). Partial melt extracted from the mantle source can contain up to $3.5 \pm 1.4 \mathrm{wt} \%$ of dissolved $\mathrm{CO}_{2}$. Assuming $\approx 7.5 \pm 2.5 \%$ of melting of the mantle plume source (Valer et al. (2017b) and references therein) and the incompatible nature of carbon during melting (see Rosenthal et al. (2015) for a review), we estimate a minimum of $716 \pm 525$ ppm of $\mathrm{C}$ in the mantle (i.e., considering $\mathrm{C}$ as fully incompatible element). This value is much larger than estimations made for MORB source mantle $(<140 \pm 30 \mathrm{ppm} \mathrm{C}$; Cartigny et al., 2008; Hirschmann and Dasgupta, 2009; Marty, 2012; Rosenthal et al., 2015), but is consistent with (1) the estimation made for the bulk mantle $(765 \pm 300$ ppm C; Marty, 2012) and (2) recent studies pointing out that carbon content in the mantle may be strongly underestimated (Anderson and Poland, 2017). According to our calculations, most of the $\mathrm{CO}_{2}(68 \pm 13 \%)$ is lost early, leading to partially degassed primary melts $\left(\mathrm{CO}_{2}=1.1 \pm 0.9 \mathrm{wt} \%\right)$ ponding at around $1 \mathrm{GPa}$ in the upper mantle.

In the upper mantle (30-11 km bsl), melts undergo early differentiation and extensive degassing as suggested by the composition of related melt inclusions $(\mathrm{MgO}<10 \mathrm{wt} \%$ in PDC; Bureau et al., 1998), the low-magnesium olivines $\left(\mathrm{Fo}_{<87}\right.$; this study; Bureau et al., 1998) and the low $\delta^{13} \mathrm{C}$ values measured in FI from olivines of peripheral pyroclasts $(<-5 \%)$. At the depth of the mantle-crust underplating layer, $90 \pm 7 \mathrm{wt} \%$ of the initial $\mathrm{CO}_{2}$ is already lost (Figs. 8 and 9). Long lasting magma storage and complex thermal paths of magmatic cumulates emplaced at the depth of the underplating layer may favor (i) FI volumetric resetting and re-equilibration processes, and (ii) melt homogenization (Jennings et al., 2017).

Melts reaching the central magmatic reservoirs at crustal level are even more evolved $\left(\mathrm{Fo}_{<85}\right)$ and degassed (Figs. 6, 8

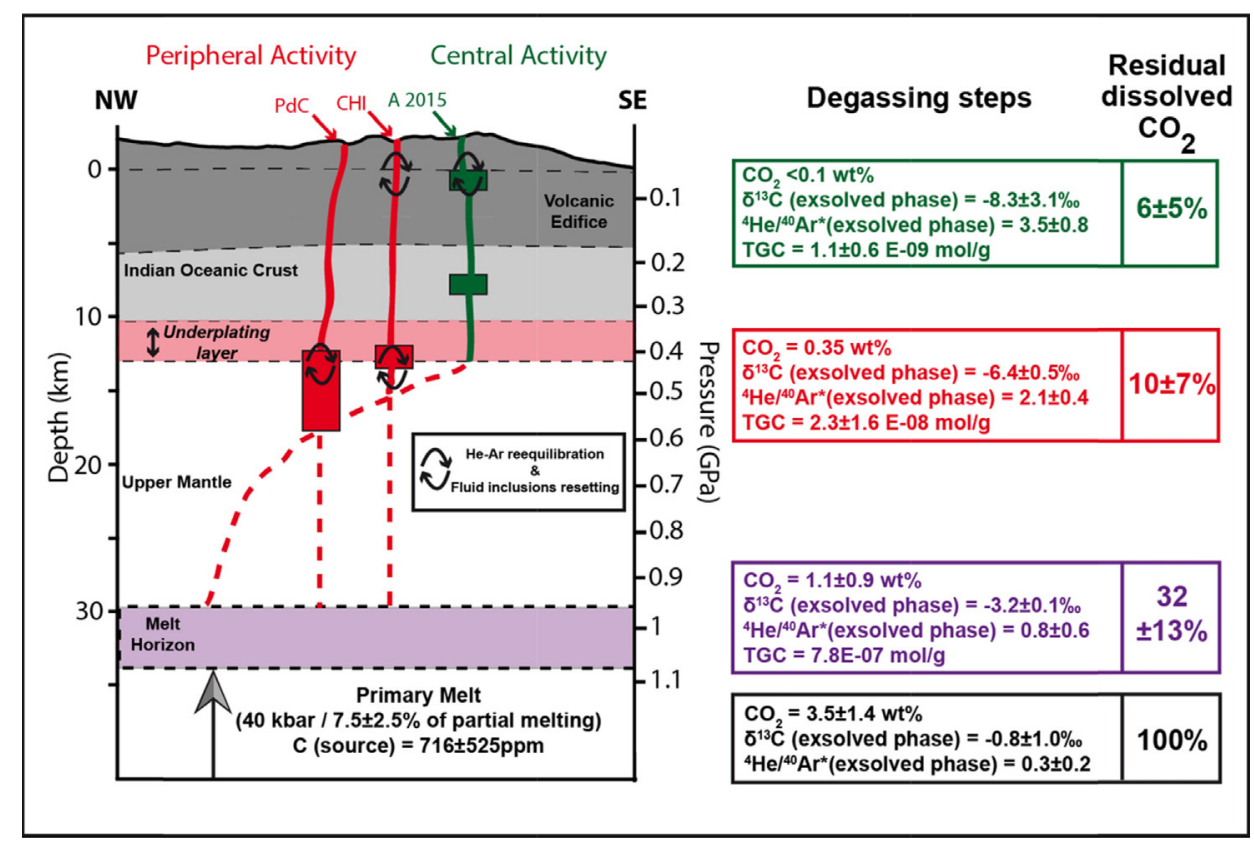

Fig. 9. Conceptual model of degassing in the magmatic plumbing system of PdF. Multistep magma ponding enhance extensive degassing, reequilibration processes, melt differentiation and volumetric resetting of fluid inclusions. Thick coloured dashed lines highlight potential magmatic pathways (Michon et al., 2015; Boudoire, 2017). 
and 9) than peripheral melts. This is consistent with the fact that the central and frequent activity of PdF volcano emits degassed magmas and is associated with very weak gas emissions (Liuzzo et al., 2015; Di Muro et al., 2016). Our findings contribute to explain the absence of permanent and sustained $\mathrm{CO}_{2}$-rich fumarolic and soil emissions inside the PdF caldera as well as in most of the parts of La Réunion island. We have estimated that early and extensive degassing $(94 \pm 5 \%)$ can lower $\delta^{13} \mathrm{C}$ values of magmatic fluids down to about $-8 \%$. Such negative values raise important issues regarding the inferences made about the contribution of exogenous processes in low carbon isotopic signatures of $\mathrm{CO}_{2}$. In fact low carbon isotope values in volcanic gas emissions are often attributed to dissolution process or carbonate precipitation (Hoefs, 2015). Interestingly, the highest $\delta^{13} \mathrm{C}$ values measured at $\mathrm{PdF}$ (in a tunnel) since the 2007 major eruption has similar values $(-8.2 \pm 0.3 \%$; Liuzzo et al., 2015), and could thus correspond to a late stage of degassing in intracrustal conditions (Fig. 9).

\subsection{Comparison with other ocean basaltic volcanoes and involvements regarding mantle $\mathrm{CO}_{2}$}

The extensive degassing we argue below PdF is unusual and appears in contrast with observations made on other ocean basaltic volcanoes like Kilauea. As a matter of fact, at Kilauea (1) high $\mathrm{CO}_{2}$ fluxes are reported at the surface with a high carbon isotope signature, ranging from -3.4 to $-4 \%$ (Gerlach and Taylor, 1990; Gerlach et al., 2002; Burton et al., 2013; Poland et al., 2014), and (2) erupted melts are primitive ( $\mathrm{MgO}$-rich melts and Fo-rich olivines; Helz et al., 2014) leading to the emission of tholeiitic basalts. Actually, the main similarity highlighted by this study between both volcanoes, is the presence of a deep magma ponding zone (ca. $30 \mathrm{~km}$-depth) characterized by (1) a similar dissolved $\mathrm{CO}_{2}$ content $(1.1 \pm 0.9 \mathrm{wt} \%$ at PdF; 0.7-1.2 wt \% at Kilauea; Gerlach et al., 2002; Wech and Thelen, 2015; Anderson and Poland, 2017) and (2) a similar carbon isotopic signature in the exsolved vapor phase $(-3.2 \pm 0.1 \%$ at $\mathrm{PdF} ;-3.4$ down to $-4 \%$ at Kilauea; Gerlach et al., 2002; Poland et al., 2014). These features suggest that the main differences regarding magma evolution of both volcanoes are related to magmatic processes occurring during magma ascent and ponding in the last $30 \mathrm{~km}$-depth. Recent studies have shown that PdF melts undergo numerous stages of differentiation in the upper mantle and the crust due to the presence of multiple magma ponding zones (Bureau et al., 1998; Michon et al., 2015; this work). Conversely, at Kilauea, Rae et al. (2016) have shown that magma ascent could be extremely fast from 45 to $65 \mathrm{~km}$-depth, as short as weeks to months that could be partially related to the more important magma supply at Kilauea (Poland et al., 2014). Jaupart (1998) has shown that slow magma ascents favor extensive degassing whereas fast magma ascents are more able to limit the degassing. Similarly, we argue that multiple magma ponding zones in the upper mantle, then in the crust, may account for an early extensive degassing and differentiation, characterizing PdF melts.
We infer that the mantle/crust underplating layer seems to play a critical role in the differentiation and degassing of PdF melts, and opens new insights on the following issues:

(1) the high extent of $\mathrm{CO}_{2}$ degassing during magma ponding at the depth of the mantle-crust underplating layer may represent a worldwide feature rather than a process specific to La Réunion Island. Actually, our model (Fig. 8) might be a classical model for numerous other ocean basaltic volcanoes, where barometric estimations evidence the presence of multiple deep magma ponding zones playing a major role in melt differentiation as e.g. Azores, Cape Verde, Canaries Islands (Zanon and Frezzotti, 2013; Klügel et al., 2015; Longpré et al., 2017),

(2) the low $\delta^{13} \mathrm{C}$ signature inferred for mantle reservoirs ( $-6 \%$; Loihi, Pitcairn; down to $-8 \%$ in MORB mantle, e.g., Sano and Marty, 1995; Deines, 2002; Aubaud et al., 2004 and references therein) could already reflect an early stage of degassing in the upper mantle rather than a contribution of recycled carbon (Exley et al., 1986; Aubaud et al., 2006), or a mantle heterogeneity.

Consequently, the total budget of mantle $\mathrm{CO}_{2}$ may be strongly underestimated when based on gas emission at the surface, on dissolved $\mathrm{CO}_{2}$ from melt inclusions or calculated considering the low carbon isotopic signature of $\mathrm{CO}_{2}$ in MORB glasses as starting conditions (Aubaud et al., 2006; Burton et al., 2013; Barry et al., 2014). For instance, previous estimations at $\mathrm{PdF}$ were based on a maximum dissolved $\mathrm{CO}_{2}$ content of $1 \mathrm{wt} \%$ in melt (Bureau et al., 1998), i.e. 2-5 times less than our estimation $(3.5 \pm 1.4 \mathrm{wt} \%)$. Our study fully supports similar recent revaluations of mantle $\mathrm{CO}_{2}$ like (i) at Kilauea by coupling volcanic $\mathrm{CO}_{2}$ emission rates with probabilistic magma supply rates (Anderson and Poland, 2017) and, (ii) at El Hierro based on the highest $\mathrm{CO}_{2}$ contents ever measured in melt inclusions from ocean island volcano (Longpré et al., 2017). Note that at El Hierro, these authors have estimated a primitive dissolved $\mathrm{CO}_{2}$ content in the range 2.5-5.0 $\mathrm{wt} \%$ (by extrapolation to undegassed $\mathrm{CO}_{2} / \mathrm{Nb}$ ), thus overlapping our estimation for PdF melts $(3.5 \pm 1.4 \mathrm{wt} \%)$.

Our reevaluation of the mantle $\mathrm{CO}_{2}$ beneath $\mathrm{PdF}$ opens new prospects regarding past climate dynamics and its links with the volcanic activity (Anderson and Poland, 2017; Gutjahr et al., 2017; Hasenclever et al., 2017; Kobashi et al., 2017; Tobin et al., 2017). More generally, this large amount of mantle $\mathrm{CO}_{2}$ opens up the possibility that deep Earth volatile cycle related to OIB needs a complete reevaluation, as suggested by some high H/C OIB sources that are probably overestimated (Hirschmann \& Dasgupta, 2009). Therefore, we strongly encourage further studies to reevaluate the global volcanic volatile budget induced by these new estimations of the initial mantle carbon and investigate past and potential future effects on the Earth atmosphere during major eruptions.

Finally, but not least important, this works suggest that monitoring of $\delta^{13} \mathrm{C},{ }^{4} \mathrm{He} /{ }^{40} \mathrm{Ar}^{*},{ }^{4} \mathrm{He} / \mathrm{CO}_{2}$ temporal variations in surface gas emissions of volcanoes characterized by very frequent eruptions may track deep magma arrival 
and constrain the degassing pressure from various parts of a plumbing system. Actually, the highest $\delta^{13} \mathrm{C}$ values recognized in gas emissions at La Réunion are around $-6 \%$ with ${ }^{4} \mathrm{He} /{ }^{40} \mathrm{Ar}^{*} \sim 1.75$ (Cilaos free gases; OVPF database; Marty et al., 1992), probably tracking a contribution of latedegassed melts stored at the depth of the underplating layer as inferred by PDC melts.

\section{CONCLUSIONS}

Deep degassing below ocean basaltic volcanoes is still poorly constrained and only a few studies quantify the degassing extent as a function of depth. Here, we focused on one of the most active volcanoes on Earth, the Piton de la Fournaise volcano, whose gas emissions at the surface are very weak in spite of its frequent eruptions. This anomalous behavior opens an important issue whether gases released from magma may escape from lateral and submarine paths of ascent or whether the subaerial weak measured emissions reflect a very degassed system at depth. In order to address this question, we have studied a set of crystals from fast quenched pyroclasts and enclaves sampled both in the peripheral and in the currently active central area. Coupling barometric estimations from olivine FIs with mineral chemistry, carbon isotopes of $\mathrm{CO}_{2}$ and noble gases in FIs we infer that peripheral products are generally more primitive, gasricher, and have a deeper (mantle) origin whereas, the central (intracaldera) ones are fed by more evolved and degassed magmas stored at shallower crustal levels.

Based on $\mathrm{He}-\mathrm{Ar}-\mathrm{CO}_{2}$ systematics, we quantify the extent of degassing from the upper mantle to the magmatic plumbing system beneath the volcano. At PdF, our data and modeling are in agreement with a predominant open system equilibrium degassing. Coupling barometric estimations and melt inclusions composition with carbon isotopes and noble gases systematics permit us to propose that:

(1) primary basaltic melts of PdF have a dissolved $\mathrm{CO}_{2}$ content around $3.5 \pm 1.4 \mathrm{wt} \%$; this study), significantly higher than previous estimated $(1 \mathrm{wt} \%$, Bureau et al., 1998) and involving a carbon-rich mantle plume source $(716 \pm 525 \mathrm{ppm} \mathrm{C})$,

(2) $\delta^{13} \mathrm{C}$ of primary vapor phase is estimated to be -0.5 $\pm 0.5 \%$,

(3) melt ponding at mantle lithospheric depth $(30 \mathrm{~km}-$ depth) has already undergone almost $68 \pm 13 \%$ of degassing,

(4) multiple magma ponding zones in the last $30 \mathrm{~km}$ permit advanced melt differentiation and extensive degassing $(90 \pm 7 \%)$ and account for the weakness of $\mathrm{CO}_{2}$ gas emissions and the emission of relatively evolved basalts in the central active area,

(5) central melts erupted by the most active area are even more degassed and this might explain the very low $\delta^{13} \mathrm{C}$ signature measured in surface gases (down to $-8 \%$ ). We point out that this low isotopic signature could be common in volcanic gases, and reflect extensive $\mathrm{CO}_{2}$ degassing during magma ascent towards the central part of the plumbing system (up to $94 \pm 5 \mathrm{wt} \%$ in this study).
We highlight that the main difference in early deep degassing between PdF and other oceanic islands like Kilauea appears to be related to the presence of multiple magma ponding zones starting already in the upper mantle ( $<30 \mathrm{~km}$-depth) beneath PdF, leading to extensive differentiation and degassing. This model might be applied to numerous ocean basaltic volcanoes where similar plumbing systems are recognized. Consequently, important implications come for the current budgets estimations of $\mathrm{CO}_{2}$ degassed from the Earth mantle, which could be largely underestimated. For instance, in this study we provide a new estimation of the carbon content in the mantle below $\operatorname{PdF}(716 \pm 525 \mathrm{ppm} \mathrm{C})$ that is considerably higher than the few previous calculations performed for Ocean Island Basalts (OIB) systems but is consistent with the recent reevaluation of the volcanic carbon budget made by the scientific community.

Finally, this study opens exciting perspectives regarding both volcanic volatile budget, $\mathrm{CO}_{2}$ recycling in the mantle, past climate dynamics and monitoring strategy, especially for the Deep Carbon Observatory community. The temporal variability of $\delta^{13} \mathrm{C}$ could bring strong information regarding magmatic dynamics occurring in the plumbing system.

\section{ACKNOWLEDGMENTS}

M. Moreira and T. Staudacher are gratefully acknowledged for providing samples (ILR84-4) from their personal collection in order to test the accuracy of our analysis with respect to previous works in literature. We are also in debt with Mariano Tantillo, Mariagrazia Misseri, Ygor Oliveri and Aldo Sollami for their assistance during noble gases and $\mathrm{CO}_{2}$ isotope analysis as well as with Chiara Alessi and Mariagrazia Misseri for samples preparation. Alain Barrère is acknowledged for providing the DUN-25M submarine dunite sample. Constructive comments by Peter Barry, Soumen Mallick and one anonymous reviewer are acknowledged for improving the quality of the manuscript. The Universite de La Réunion and the ANR "STRAP" (ANR-14-CE03-0004) have funded this work. INGV of Palermo provided laboratory facilities. This is IPGP contribution number 3953.

\section{SUPPLEMENTARY MATERIAL}

Supplementary data (Appendix A, B, C, D) associated with this article can be found, in the online version, at https://doi.org/10.1016/j.gca.2018.06.004.

\section{REFERENCES}

Aiuppa A. and Federico C. (2004) Anomalous magmatic degassing prior to the 5th April 2003 paroxysm on Stromboli. Geophys. Res. Lett. 31, L14607. https://doi.org/10.1029/2004GL020458.

Albarède A., Luais B., Fitton G., Semet M., Kaminski E., Upton B. G. J., Bachèlery P. and Cheminée J.-L. (1997) The geochemical regimes of Piton de la Fournaise volcano (Réunion) during the last 530000 years. Journal of Petrology 38(2), 171-201.

Allard P., Carbonnelle J., Dajlevic D., Le Bronec J., Morel P., Robe M. C., Maurenas J. M., Faivre-Pierret R., Martin D., Sabroux J. C. and Zettwoog P. (1991) Eruptive and diffuse emissions of $\mathrm{CO} 2$ from Mount Etna. Nature 351(6325), 387-391 
Anderson K. R. and Poland M. P. (2017) Abundant carbon in the mantle beneath Hawai'i. Nat. Geosci. https://doi.org/10.1038/ NGEO3007.

Aubaud C., Pineau F., Jambon A. and Javoy M. (2004) Kinetic disequilibrium of $\mathrm{C}, \mathrm{He}, \mathrm{Ar}$ and carbon isotopes during degassing of mid-ocean ridge basalts. Earth Planet. Sci. Lett. 222(2), 391-406.

Aubaud C., Pineau F., Hékinian R. and Javoy M. (2005) Degassing of $\mathrm{CO}_{2}$ and $\mathrm{H}_{2} \mathrm{O}$ in submarine lavas from the Society hotspot. Earth Planet Sci. Lett. 235, 511-527.

Aubaud C., Pineau F., Hékinian R. and Javoy M. (2006) Carbon and hydrogen isotope constraints on degassing of $\mathrm{CO}_{2}$ and $\mathrm{H}_{2} \mathrm{O}$ in submarine lavas from the Pitcairn hotspot (South Pacific). Geophys. Res. Lett. 33.

Barry P. H., Hilton D. R., Füri E., Halldórsson S. A. and Grönvold K. (2014) Carbon isotope and abundance systematics of Icelandic geothermal gases, fluids and subglacial basalts with implications for mantle plume-related $\mathrm{CO}_{2}$ fluxes. Geochim. Cosmochim. Acta 134, 74-99.

Boivin P. and Bachèlery P. (2009) Petrology of 1977 to 1998 eruptions of Piton de la Fournaise, La Réunion Island. J. Volcanol. Geothermal Res. 184, 109-125.

Bolder-Schrijver L., Kriegsmann L. and Touret J. L. R. (2000) Primary carbonate/CO2 inclusions in sapphirine-bearing granulites from central Sri-Lanka. J. Metamorphic Geol. 18, 259-269.

Bottinga Y. (1969) Calculated fractionation factors for carbon and hydrogen isotope exchange in the system calcite- $\mathrm{CO}_{2}$-graphitemethane-hydrogen and water vapour. Geochim. Cosmochim. Acta 33, 49-64.

Boudoire G. (2017) Architecture and dynamics of magmatic systems linked to basaltic volcanoes: a case study of Piton de la Fournaise. PhD thesis. Université de La Réunion, SaintDenis, France, 500pp. http://doi.org/10.13140/RG.2.2.19137. 04966.

Boudoire G., Di Muro A., Liuzzo M., Ferrazzini V., Peltier A., Gurrieri S., Michon L., Giudice G., Kowalski P. and Boissier P. (2017a) New perspectives on volcano monitoring in a tropical environment: continuous measurements of soil $\mathrm{CO} 2$ flux at Piton de la Fournaise (La Réunion Island, France). Geophys. Res. Lett. 44. https://doi.org/10.1002/ 2017 GL074237.

Boudoire G., Liuzzo M., Di Muro A., Ferrazzini V., Michon L., Grassa F., Derrien A., Villeneuve N., Bourdeu A., Brunet C., Giudice G. and Gurrieri S. (2017b) Investigating the deepest part of a volcano plumbing system: evidence for an active magma path below the western flank of Piton de la Fournaise (La Réunion Island). J. Volcanol. Geotherm. Res. https://doi. org/10.1016/j.jvolgeores.2017.05.026.

Bouhifd M. A. and Jephcoat A. P. (2006) Aluminium control of argon solubility in silicate melts under pressure. Nature 439 (7079), 961.

Brugier Y.-A. (2016) Magmatologie du Piton de la Fournaise (Ile de la Réunion) - Approche Volcanologique, Pétrologique et Expérimentale. Ph.D. thesis. Université d'Orléans, Orléans, France, 273pp.

Bureau H., Pineau F., Metrich N., Semet M. P. and Javoy M. (1998) A melt and fluid inclusion study of the gas phase at Piton de la Fournaise volcano (Reunion Island). Chem. Geol. 147, $115-130$.

Burnard P. (2004) Diffusive fractionation of noble gases and helium isotopes during mantle melting. Earth Planet. Sci. Lett. 220(3-4), 287-295.

Burnard P., Harrison D., Turner G. and Nesbitt R. (2003) Degassing and contamination of noble gases in Mid-Atlantic Ridge basalts. Geochem., Geophys., Geosyst. 4(1), 1-20.
Burnard P., Reisberg L. and Colin A. (2014) An observed link between lithophile compositions and degassing of volatiles $(\mathrm{He}$, $\mathrm{Ar}, \mathrm{CO} 2$ ) in MORBs with implications for Re volatility and the mantle C/Nb ratio. Earth Planet. Sci. Lett. 395, 159-167.

Burton M. R., Sawyer G. M. and Granieri D. (2013) Deep carbon emissions from volcanoes. Rev. Mineral. Geochem. 75, 323-354.

Capasso G., Carapezza M. L., Federico C., Inguaggiato S. and Rizzo A. (2005) Geochemical variations in fluids from Stromboli volcano (Italy): early evidences of magma ascent during 2002-2003 eruption. Bull. Volcanol. https://doi.org/10.1007/ s00445-005-0427-5.

Caracausi A., Favara R., Giammanco S., Italiano F., Nuccio P. M., Paonita A., Pecoraino G. and Rizzo A. (2003) Mount Etna: geochemical signals of magma ascent and unusually extensive plumbing system. Geophys. Res. Lett. 30(2), 1057. https://doi. org/10.1029/2002GL015463.

Carn S. A., Fioletov V. E., McLinden C. A., Li C. and Krotkov N. A. (2017) A decade of global volcanic SO2 emissions measured from space. Sci. Reports 7.

Carroll M. R. and Stolper E. M. (1991) Argon solubility and diffusion in silica glass: Implications for the solution behavior of molecular gases. Geochim. Cosmochim. Acta 55(1), 211-225.

Carroll M. R. and Stolper E. M. (1993) Noble gas solubility in silicate and glasses: new experimental results for argon and the relationship between solubility and ionic porosity. Geochim. Cosmochim. Acta 57, 5039-5051.

Cartigny P., De Corte K., Shatsky V. S., Ader M., De Paepe P., Sobolev N. and Javoy M. (2001) The origin and formation of metamorphic microdiamonds from the Kokchetav massif, Kazakhstan: a nitrogen and carbon isotope study. Chem. Geol. 176(1), 265-281.

Cartigny P., Pineau F., Aubaud C. and Javoy M. (2008) Towards a consistent mantle car-bon flux estimate: insights from volatile systematics $(\mathrm{H} 2 \mathrm{O} / \mathrm{Ce}$, delta $\mathrm{D}, \mathrm{CO} 2 / \mathrm{Nb})$ in the North Atlantic mantle (14 degrees N and 34 degrees N). Earth Planet Sci. Lett. 265, 672-685.

Chamorro-Perez E., Gillet P. and Jambon A. (1996) Argon solubility in silicate melts at very high pressures. Experimental set-up and preliminary results for silica and anorthite melts. Earth Planet. Sci. Lett. 145(1-4), 97-107.

Chamorro-Perez E., Gillet P., Jambon A., Badro J. and McMillan P. (1998) Low argon solubility in silicate melts at high pressure. Nature 393(6683), 352.

Charvis P., Laesanpura A., Gallart J., Hirn A., Lepine J., de Voogd B., Minshull T. A., Hello Y. and Pontoise B. (1999) Spatial distribution of hotspot material added to the lithosphere under La Reunion, from wide-angle seismic data. J. Geophys. Res. 104, 2875-2893.

Coppola D., Di Muro A., Peltier A., Villeneuve N., Ferrazzini V., Favalli M., Bachèlery P., Gurioli L., Harris A. J. L., Moune S., Vlastélic I., Galle B., Arellano S. and Aiuppa A. (2017) Shallow system rejuvenation and magma discharge trends at Piton de la Fournaise volcano (La Réunion Island). Earth Planet. Sci. Lett. 463, 13-24.

Correale A., Paonita A., Martelli M., Rizzo A., Rotolo S. G., Corsaro R. A. and Di Renzo V. (2014) A two-component mantle source feeding Mt. Etna magmatism: insights from the geochemistry of primitive magmas. Lithos 184-187, 243-258. https://doi.org/10.1016/j.lithos.2013.10.038.

Courtillot V., Davaille A., Besse J. and Stock J. (2003) Three distinct types of hotspots in the Earth's mantle. Earth Planet. Sci. Lett. 205(3-4), 295-308.

Danyushevsky L. V., McNeill A. W. and Sobolev A. V. (2002) Experimental and petrological studies of melt inclusions in phenocrysts from mantle-derived magmas: an overview of techniques, advantages and complications. Chem. Geol. 183, 5-24. 
Dasgupta R. and Hirschmann M. M. (2010) The deep carbon cycle and melting in Earth's interior. Earth Plant Sci. Lett. 298, 1-13.

Deines P. (2002) The carbon isotope geochemistry of mantle xenoliths. Earth-Sci. Rev. 58, 247-278.

Di Muro A., Métrich N., Allard P., Aiuppa A., Burton M., Galle B. and Staudacher T. (2016) Magma Degassing at Piton de la Fournaise Volcano, in Active volcanoes of the southwest Indian Ocean: Piton de la Fournaise and Karthala. In Active Volcanoes of the World (eds. P. Bachèlery, J. F. Lénat, A. Di Muro and L. Michon). Springer, Berlin, pp. 203-222.

Di Muro A., Métrich N., Vergani D., Rosi M., Armienti P., Fougeroux T., Deloule E., Arienzo I. and Civetta L. (2014) The shallow plumbing system of Piton de la Fournaise Volcano (La Réunion Island, Indian Ocean) revealed by the major 2007 caldera-forming eruption. J. Petrol. 55, 1287-1315.

Di Muro A., Staudacher T., Ferrazzini V., Métrich N., Villemant B., Besson P. and Garofalo C. (2015) Shallow magma storage at Piton de la Fournaise Volcano after the 2007 summit caldera collapse tracked in Pele's hairs. In Hawaiian Volcanoes: from Source to Surface. Geophysical Monograph Series (eds. R. Carey, V. Cayol, M. Poland and D. Weis), pp. 189-212.

Duan X. (2014) A general model for predicting the solubility behavior of $\mathrm{H}_{2} \mathrm{O}-\mathrm{CO}_{2}$ fluids in silicate melts over a wide range of pressure, temperature and compositions. Geochim. Cosmochim. Acta 125, 582-609.

Dubacq B., Bickle M. J., Wigley M., Kampman N., Ballentine C. J. and Lollar B. (2012) Noble gas and carbon isotopic evidence for $\mathrm{CO} 2$-driven silicate dissolution in a recent natural $\mathrm{CO} 2$ field. Earth Planet. Sci. Lett. 341, 10-19.

Exley R. A., Mattey D. P., Clague D. A. and Pillinger C. T. (1986) Carbon isotope systematics of a mantle "hotspot": a comparison of Loihi Seamount and MORB glasses. Earth Planet. Sci. Lett. 78, 189-199.

Famin V., Welsch B., Okumura S., Bachèlery P. and Nakashima S. (2009) Three differentiation stages of a single magma at Piton de la Fournaise (Réunion hotspot). Geochem. Geophys. Geosyst. 10, Q01007. https://doi.org/10.1029/2008GC002015.

Fontaine F. R., Barruol G., Tkalčić H., Wölbern I., Rümpker G., Bodin T. and Haugmard M. (2015) Crustal and uppermost mantle structure variation beneath La Réunion hotspot track. Geophys. J. Int. 203, 107-126.

Fretzdorff S. and Haase K. M. (2002) Geochemistry and Petrology of lavas from the submarine flanks of Réunion Island (western Indian ocean): implications for magma genesis and the mantle source. Mineral. Petrol. 75, 153-184.

Frezzotti M. L. and Touret J. L. R. (2014) $\mathrm{CO}_{2}$, carbonate-rich melts, and brines in the mantle. Geosci. Front. 5, 697-710.

Füri E., Hilton D. R., Murton B. J., Hémond C., Dyment J. and Day J. M. D. (2011) Helium isotope variations between Réunion Island and the Central Indian Ridge $\left(17^{\circ}-21^{\circ} \mathrm{S}\right)$ : new evidence for ridge-hot spot interaction. J. Geophys. Res. 116, B02207. https://doi.org/10.1029/2010JB007609.

Gale A., Dalton C. A., Langmuir C. H., Su Y. and Schilling J. G. (2013) The mean composition of ocean ridge basalts. Geochem., Geophys., Geosyst. 14(3), 489-518.

Gallart J., Driad L., Charvis P., Sapin M., Hirn A., Diaz J., de Voogd B. and Sachpazi M. (1999) Perturbation to the lithosphere along the hotspot track of La Réunion from an offshore-onshore seismic transect. J. Geophys. Res. 104, 2895-2908.

Gautheron C., Cartigny P., Moreira M., Harris J. W. and Allègre C. J. (2005) Evidence for a mantle component shown by rares gases, $\mathrm{C}$ and $\mathrm{N}$-isotopes in polycristalline diamonds from Orapa (Botswana). Earth Planet. Sci. Lett. 240, 559-572.

Gennaro M. E., Grassa F., Martelli M., Renzulli A. and Rizzo A. L. (2017) Carbon isotope composition of CO2-rich inclusions in cumulate-forming mantle minerals from Stromboli volcano (Italy). J. Volcanol. Geotherm. Res. 346, 95-103. https://doi. org/10.1016/j.jvolgeores.2017.04.001.

Gerbault M., Fontaine F. J., Rabinowicz M. and Bystricky M. (2017) Elastic flexure controls magma trajectories and explains the offset of primary volcanic activity upstream of mantle plume axis at La Réunion and Hawaii hotspot islands. Earth Planet. Sci. Lett. 462, 142-156.

Gerlach T. M., McGee K. A., Elias T., Sutton A. J. and Doukas M. P. (2002) Carbon dioxide emission rate of Kilauea Volcano: implications for primary magma and the summit reservoir. $J$. Geophys. Res. 107, ECV-3.

Gerlach T. M. and Taylor B. E. (1990) Carbon isotope constraints on degassing of carbon dioxide from Kilauea volcano. Geochim. Cosmochim. Acta 54, 2051-2058.

Gilfillana S., Haszedlinea S., Stuartb F., Gyoreb D., Kilgallona R. and Wilkinsona M. (2014) The application of noble gases and carbon isotopes in tracing the fate, migration and storage of CO2. Energy Proc. 63, 4123-4133.

Gillot P.-Y. and Nativel P. (1989) Eruptive history of the Piton de la Fournaise volcano, Reunion Island, Indian Ocean. $J$. Volcanol. Geotherm. Res. 36, 53-65.

Gonnermann H. M. and Mukhopadhyay S. (2007) Non-equilibrium degassing and a primordial source for helium in oceanisland volcanism. Nat. Lett. 449, 1037-1040.

Graham D., Lupton J., Albarède F. and Condomines M. (1990) Extreme temporal homogeneity of helium isotopes at Piton de la Fournaise, Réunion Island. Nature 347, 545-548.

Gutjahr M., Ridgwell A., Sexton P. F., Anagnostou E., Pearson P. N., Pälike H., Norris R. D., Thomas E. and Foster G. L. (2017) Very large release of mostly volcanic carbon during the Palaeocene-Eocene Thermal Maximum. Nature 548(7669), 573.

Hansteen T. H. and Klügel A. (2008) Fluid inclusion thermobarometry as a tracer for magmatic processes. In Reviews in Mineralogy and Geochemistry (eds. K. Putirka and F. Tepley). Mineralogical Society of America, pp. 142-177.

Hanyu T., Dunai T. J., Davies G. R., Kaneoka I., Nohda S. and Uto K. (2001) Noble gas study of the Reunion hot spot: evidence for distinct less-degassed mantle sources. Earth Planet. Sci. Lett. 193, 83-98. https://doi.org/10.1016/S0012-821X(01) 00489-7.

Hasenclever J., Knorr G., Rüpke L. H., Köhler P., Morgan J., Garofalo K., Barker S., Lohmann G. and Hall I. R. (2017) Sea level fall during glaciation stabilized atmospheric $\mathrm{CO} 2$ by enhanced volcanic degassing. Nat. Commun. 8, 15867.

Helz R. T., Clague D. A., Sisson T. W. and Thornber C. R. (2014) Petrologic insights into basaltic volcanism at historically active Hawaiian volcanoes. In Characteristics of Hawaiian Volcanoes (eds. M. P. Poland, T. J. Takahashi and C. M. Landowski). U. S. Geol. Surv. Prof. Pap. 1801, 179-234, U.S. Geol. Surv., Reston, Va., http://doi.org/10.3133/pp18015.

Hirschmann M. M. and Dasgupta R. (2009) The H/C ratios of Earths near-surface and deep reservoirs, and consequences for deep Earth volatile cycles. Chem. Geol. 262, 4-16.

Hoefs J. (2015) Stable Isotope Geochemistry. Springer.

Iacono-Marziano G., Paonita A., Rizzo A., Gaillard F. and Scaillet B. (2010) Noble gas solubility in silicate melts: new experimental results and a comprehensive model of the effects of liquid composition, temperature and pressure. Chem. Geol. 279, $145-157$.

Jambon A., Weber H. W. and Braun O. (1986) Solubility of He, $\mathrm{Ne}, \mathrm{Ar}, \mathrm{Kr}$ and $\mathrm{Xe}$ in a basalt melt in the range $1250-1600^{\circ} \mathrm{C}$ : geochemical implications. Geochim. Cosmochim. Acta 50(3), 401-408.

Jaupart C. (1998) Gas loss from magmas through conduit walls. In The Physics of Explosive Volcanic Eruptions (eds. J. S. Gilbert 
and R. S. J. Sparks). Geological Society, London, Special Publications, 145, 73-90.

Javoy M. and Pineau F. (1991) The volatiles record of a "popping" rock from the Mid-Atlantic Ridge at $14 \mathrm{~N}$ : chemical and isotopic composition of gas trapped in the vesicles. Earth and Planetary Science Letters 107(3-4), 598-611.

Javoy M., Pineau F. and Iiyama I. (1978) Experimental determination of the isotope fractionation between gaseous $\mathrm{CO}_{2}$ and carbon dissolved in tholeiitic magma; a preliminary study. Contrib. Mineral. Petrol. 67, 35-39.

Jennings E. S., Gibson S. A., Maclennan J. and Heinonen J. S. (2017) Deep mixing of mantle melts beneath continental flood basalt provinces: constraints from olivine-hosted melt inclusions in primitive magmas. Geochim. Cosmochim. Acta 196, 36-57.

Kendrick M. A. and Phillips D. (2009) New constraints on the release of noble gases during in vacuo crushing and application to scapolite $\mathrm{Br}-\mathrm{Cl}-\mathrm{I}$ and $40 \mathrm{Ar} / 39 \mathrm{Ar}$ age determinations. Geochim. Cosmochim. Acta 73, 5673-5692.

Klügel A., Longpré M. A., Garcia-Canada L. and Stix J. (2015) Deep intrusions, lateral magma transport and related uplift at ocean island volcanoes. Earth Planet. Sci. Lett. 431, 140-149.

Kobashi T., Menviel L., Jeltsch-Thömmes A., Vinther B. M., Box J. E., Muscheler R., Nakaegawa T., Pfister P. L., Döring M., Leuenberger M. and Wanner H. (2017) Volcanic influence on centennial to millennial Holocene Greenland temperature change. Sci. Reports 7(1), 1441

Lamadrid H. M., Moore L. R., Moncada D., Rimstidt J. D., Burruss R. C. and Bodnar R. J. (2016) Reassessment of the Raman $\mathrm{CO}_{2}$ densimeter. Chem. Geol.. https://doi.org/10.1016/j. chemgeo.2016.12.034.

Lange R. L. and Carmichael I. S. (1990) Thermodynamic properties of silicate liquids with emphasis on density, thermal expansion and compressibility. Reviews in Mineralogy and Geochemistry 24(1), 25-64.

Lee H., Muirhead J. D., Fischer T. P., Ebinger C. J., Kattenhorn S. A., Sharp Z. and Kianji G. (2016) Massive and prolonged deep carbon emissions associated with continental rifting. Nat. Geosci. 9(2), 145 .

Le Guern F., Giggenbach W., Tazieff H. and Zettwoog P. (1975) Etude des fluctuations de la phase gazeuse à l'étang de lave de l'Erta Ale (Ethiopie). C.R. Acad. Sci. Paris 280, 1959-1962.

Le Guern F., Morel P., Tazieff H. and Vavasseur C. (1982) Volcanic plume thermal radiation: 1972 eruption of piton de la fournaise, Réunion Island. J. Volcanol. Geotherm. Res. 12(1-2), $167-175$.

Liuzzo M., Di Muro A., Giudice G., Michon L., Ferrazzini V. and Gurrieri S. (2015) New evidence of $\mathrm{CO}_{2}$ soil degassing anomalies on Piton de la Fournaise volcano and the link with volcano tectonic structures. Geochem. Geophys. Geosyst. 16. https://doi.org/10.1002/2015GC006032.

Liuzzo M., Gurrieri S., Giudice G. and Giuffrida G. (2013) Ten years of soil $\mathrm{CO}_{2}$ continuous monitoring on Mt. Etna: exploring the relationship between processes of soil degassing and volcanic activity. Geochem. Geophys. Geosyst. 14, 2886-2899.

Longpré M. A., Stix J., Klügel A. and Shimizu N. (2017) Mantle to surface degassing of carbon-and sulphur-rich alkaline magma at El Hierro, Canary Islands. Earth Planet. Sci. Lett. 460, $268-280$.

Luais B. (2004) Temporal changes in Nd isotope composition of Piton de la Fournaise magmatism (Réunion Island, Indian Ocean). Geochem., Geophys., Geosyst. 5, 2002 GC000502.

Maclennan J. (2017) Bubble formation and decrepitation control the $\mathrm{CO}_{2}$ content of olivine-hosted melt inclusions. Geochem., Geophys., Geosyst. 18. https://doi.org/10.1002/2016GC006633.
Macpherson C. G. and Mattey D. P. (1994) Carbon isotope variations of $\mathrm{CO}_{2}$ in Lau Basin basalts and ferrobasalts. Earth Planet. Sci. Lett. 121, 263-276.

Mahoney J. J., Duncan R. A., Khan W., Gnos E. and McCormick G. R. (2002) Cretaceous volcanic rocks of the South Tethyan suture zone, Pakistan: implications for the Réunion hotspot and Deccan Traps. Earth Planet. Sci. Lett. 203, 295-310.

Manning C. E. (2014) Geochemistry: A piece of the deep carbon puzzle. Nature Geoscience 7(5), 333.

Marrocchi Y. and Toplis M. J. (2005) Experimental determination of argon solubility in silicate melts: an assessment of the effects of liquid composition and temperature. Geochim. Cosmochim. Acta 69(24), 5765-5776.

Martelli M., Rizzo A. L., Renzulli A., Ridolfi F., Arienzo I. and Rosciglione A. (2014) Noble-gas signature of magmas from a heterogeneous mantle wedge: the case of Stromboli volcano (Aeolian Islands, Italy). Chem. Geol. 368, 39-53.

Marty B. (2012) The origins and concentrations of water, carbon, nitrogen and noble gases on Earth. Earth Planet. Sci. Lett. 313314, 56-66.

Marty B., Alexander C. M. O. D. and Raymond S. N. (2013) Primordial origins of Earth's carbon. Rev. Mineral. Geochem. 75, 149-181.

Marty B. and Jambon A. (1987) C/ ${ }^{3} \mathrm{He}$ in volatile fluxes from the solid Earth: implications for carbon geodynamics. Earth Planet. Sci. Lett. 83, 16-26.

Marty B., Meynier V., Nicolini E., Griesshaber E. and Toutain J. P. (1992) Geochemistry of gas emanations: a case study of the Réunion hot spot, Indian Ocean. App. Geochem. 8, 141-152.

Mason E., Edmonds M. and Turchyn A. V. (2017) Remobilization of crustal carbon may dominate volcanic arc emissions. Science 357(6348), 290-294.

Massin F. (2009) Transferts et Stockages Magmatiques au Piton de la Fournaise, Ph.D. thesis. Université de la Réunion, 176pp.

Matsuda J. and Marty B. (1995) The ${ }^{40} \mathrm{Ar} /{ }^{36} \mathrm{Ar}$ ratio of the undepleted mantle; a reevaluation. Geophys. Res. Lett. 22, $1937-1940$.

Mattey D. P. (1991) Carbon dioxide solubility and carbon isotope fractionation in basaltic melt. Geochim. Cosmochim. Acta 55 (11), 3467-3473.

Michael P. J. and Graham D. W. (2015) The behavior and concentration of $\mathrm{CO} 2$ in the suboceanic mantle: inferences from undegassed ocean ridge and ocean island basalts. Lithos 236, 338-351.

Michon L., Ferrazzini V., Di Muro A., Villeneuve N. and Famin V. (2015) Rift zones and magma plumbing system of Piton de la Fournaise volcano: how do they differ from Hawaii and Etna. J. Volcanol. Geotherm. Res. 303, 112-129.

Miyazaki A., Hiyagon H., Sugiura N., Hirose K. and Takahashi E. (2004) Solubilities of nitrogen and noble gases in silicate melts under various oxygen fugacities: implications for the origin and degassing history of nitrogen and noble gases in the Earth. Geochim. Cosmochim. Acta 68(2), 387-401.

Nercessian A., Hirn A., Lépine J. C. and Sapin M. (1996) Internal structure of Piton de la Fournaise volcano from seismic wave propagation and earthquake distribution. J. Volcanol. Geotherm. Res. 70, 123-143.

Oppenheimer C., Scaillet B. and Martin R. S. (2011) Sulfur degassing from volcanoes: source conditions, surveillance, plume chemistry and Earth system impacts. Rev. Mineral. Geochem. 73, 363-421. https://doi.org/10.2138/rmg.2011.73.13.

Ort M., Di Muro A., Michon L. and Bachèlery P. (2016) Explosive eruptions from the interaction of magmatic and hydrothermal systems during flank extension: the Bellecombe ashes of Piton de la Fournaise (La Réunion Island). Bull. Volcanol. 78, 5. 
Ozima M. and Podosek F. P. (1983) Noble Gas Geochemistry. Cambridge University Press.

Paonita A. (2005) Noble gas solubility in silicate melts: a review of experimentation and theory and implications regarding magma degassing processes. Ann. Geophys. 48(4/5), 647-669.

Paonita A., Caracausi A., Iacono-Marziano G., Martelli M. and Rizzo A. (2012) Geochemical evidence for mixing between fluids exsolved at different depths in the magmatic system of $\mathrm{Mt}$ Etna (Italy). Geochim. Cosmochim. Acta 84, 380-394.

Paonita A., Gigli G., Gozzi D., Nuccio P. M. and Trigila R. (2000) Investigation of the He solubility in $\mathrm{H} 2 \mathrm{O}-\mathrm{CO} 2$ bearing silicate liquids at moderate pressure: a new experimental method. Earth Planet. Sci. Lett. 181(4), 595-604.

Paonita A. and Martelli M. (2007) A new view of the He-Ar-CO2 degassing at mid-ocean ridges: homogeneous composition of magmas from the upper mantle. Geochim. Cosmochim. Acta 71 (7), 1747-1763.

Papale P., Moretti R. and Barbato D. (2006) The compositional dependence of the saturation surface of $\mathrm{H}_{2} \mathrm{O}+\mathrm{CO}_{2}$ fluids in silicate melts. Chem. Geol. 229, 78-95.

Parks M. M., Caliro S., Chiodini G., Pyle D. M., Mather T. A., Berlo K., Edmonds M., Biggs J., Nomikou P. and Raptakis C. (2013) Distinguishing contributions to diffusive CO2 emissions in volcanic areas from magmatic degassing and thermal decarbonation using soil gas 222Rn-d13C systematics: application to Santorini volcano, Greece. Earth Planet. Sci. Lett. 377378, 180-190.

Peters B. J., Day J. M. D. and Taylor L. A. (2016) Early mantle heterogeneities in the Réunion hotspot source inferred from highly sidérophiles elements in cumulate xenoliths. Earth Planet. Sci. Lett. 448, 150-160.

Pietruszka A. J., Hauri E. H. and Blichert-Toft J. (2009) Crustal contamination of mantle-derived magmas within Piton de la Fournaise volcano, Reunion island. J. Petrol. 50, 661-684.

Poland M. P., Miklius A. and Montgomery-Brown E. K. (2014) Magma supply, storage, and transport at shield-stage Hawaiian volcanoes. In Characteristics of Hawaiian Volcanoes (eds. M. P. Poland, T. J. Takahashi and C. M. Landowski). U.S. Geol. Surv. Prof. Pap. 1801, 179-234, U.S. Geol. Surv., Reston, Va., http://doi.org/10.3133/pp18015.

Poreda R. J. and Farley K. A. (1992) Rare gases in Samoan xenoliths. Earth Planet. Sci. Lett. 113, 129-144.

Putirka K. D. (2008) Thermometers and barometers for volcanic systems. Reviews in mineralogy and geochemistry 69(1), 61-120.

Rae A. S. P., Edmonds M., Maclennan J., Morgan D., Houghton B., Hartley M. E. and Sides I. (2016) Time scales of magma transport and mixing at Kilauea Volcano, Hawai'i. Geology 44, 463-466. https://doi.org/10.1130/G37800.1.

Ray M. C., Hilton D. R., Munoz J., Fischer T. P. and Shaw A. M. (2009) The effects of volatile recycling, degassing and crustal contamination on the helium and carbon geochemistry of hydrothermal fluids from the Southern Volcanic Zone of Chile. Chem. Geol. 266, 38-49.

Rizzo A. L., Barberi F., Carapezza M. L., Di Piazza A., Francalanci L., Sortino F. and D'Alessandro W. (2015) New mafic magma refilling a quiescent volcano: Evidence from He$\mathrm{Ne}-\mathrm{Ar}$ isotopes during the 2011-2012 unrest at Santorini, Greece. Geochem. Geophys. Geosyst. 16, 798-814. https://doi. org/10.1002/ 2014GC005653.

Rizzo A., Caracausi A., Favara R., Martelli M., Nuccio P. M., Paonita A., Rosciglione A. and Paternoster M. (2006) New insights into magma dynamics during last two eruptions of Mount Etna as inferred by geochemical monitoring from 2002 to 2005. Geochem. Geophys. Geosyst. 7, Q06008. https://doi. org/10.1029/2005GC001175.
Rizzo A., Grassa F., Inguaggiato S., Liotta M., Longo M., Madonia P., Brusca L., Capasso G., Morici S., Rouwet D. and Vita F. (2009) Geochemical evaluation of observed changes in volcanic activity during the 2007 eruption at Stromboli (Italy). J. Volcanol. Geoth. Res. 182, 246-254.

Robidoux P., Aiuppa A., Rotolo S. G., Rizzo A. L., Hauri E. H. and Frezzotti M. L. (2017) Volatile contents of mafic-tointermediate magmas at San Cristobal volcano in Nicaragua. Lithos 272-273, 147-163.

Roedder E. (1984) Fluid inclusions. Rev. Mineral. Mineralogical Society of America 12, 644.

Rosenthal A., Hauri E. H. and Hirschmann M. (2015) Experimental determination of $\mathrm{C}, \mathrm{F}$, and $\mathrm{H}$ partitioning between mantle minerals and carbonated basalt, $\mathrm{CO} 2 / \mathrm{Ba}$ and $\mathrm{CO} 2 / \mathrm{Nb}$ systematics of partial melting, and the $\mathrm{CO} 2$ contents of basaltic source regions. Earth Planet. Sci. Lett. 425, 77-87.

Roult G., Peltier A., Taisne B., Staudacher T., Ferrazzini V., Di Muro A. and Team O. V. P. F. (2012) A new comprehensive classification of the Piton de la Fournaise activity spanning the 1985-2010 period. Search and analysis of short-term precursors from a broad-band seismological station. J. Volcanol. Geotherm. Res. 241-242, 78-104.

Sano Y. and Marty B. (1995) Origin of carbon in fumarolic gas from island arcs. Chemical Geology 119(1-4), 265-274.

Sarda P. and Guillot B. (2005) Breaking of Henry's law for noble gas and $\mathrm{CO}_{2}$ solubility in silicate melt under pressure. Nature 436, 95-98.

Sarda P. and Moreira M. (2002) Vesiculation and vesicle loss in Mid Oceanic Ridge basalt glasses: $\mathrm{He}, \mathrm{Ne}$, Ar elemental fractionation and pressure influence. Geochem. Cosmoch. Acta 66, 1449-1458.

Scarpa R. (2001) Predicting volcanic eruptions. Science 293, 615616.

Schiano P., David K., Vlastélic I., Gannoun A., Klein M., Nauret F. and Bonnand P. (2012) Osmium isotope systematics of historical lavas from Piton de la Fournaise (Réunion Island, Indian Ocean). Contrib. Mineral. Petrol. 164(5), 805-820.

Schmidt B. C. and Keppler H. (2002) Experimental evidence for high noble gas solubilities in silicate melts under mantle pressures. Earth Planet. Sci. Lett. 195(3), 277-290.

Shaw A. M., Hilton D. R., Macpherson C. G. and Sinton J. M. (2004) The $\mathrm{CO}_{2}-\mathrm{He}-\mathrm{Ar}-\mathrm{H}_{2} \mathrm{O}$ systematics of the Manus back-arc basin: resolving source composition from degassing and contamination effects. Geochim. Cosmochim. Acta 68, 1837-1855.

Shibata T., Takahashi E. and Matsuda J. I. (1996) Noble gas solubility in binary $\mathrm{CaO}-\mathrm{SiO} 2$ System. Geophys. Res. Lett. 23 (22), 3139-3142.

Shibata T., Takahashi E. and Matsuda J. I. (1998) Solubility of neon, argon, krypton, and xenon in binary and ternary silicate systems: a new view on noble gas solubility. Geochim. Cosmochim. Acta 62(7), 1241-1253.

Shishkina T. A., Botcharnikov R. E., Holtz F., Almeev R. R., Jazwa A. M. and Jakubiak A. A. (2014) Compositional and pressure effects on the solubility of $\mathrm{H} 2 \mathrm{O}$ and $\mathrm{CO} 2$ in mafic melts. Chem. Geol. 388, 112-129.

Staudacher T., Sarda P. and Allègre C. J. (1990) Noble gas systematics of Réunion Island, Indian Ocean. Chem. Geol. 89, 1-17. https://doi.org/10.1016/0009-2541(90)90057-E.

Tazieff H. and Tonani F. (1963) Fluctuations rapides et importantes de la phase gazeuse éruptive. C.R Acad. Sci. 257, 3985-3987.

Tedesco D., Tassi F., Vaselli O., Poreda R., Darrah T., Cuoco E. and Yalire M. M. (2010) Gas isotopic signatures (He, C, and $\mathrm{Ar}$ ) in the Lake Kivu region (western branch of the East African rift system): geodynamic and volcanological implications. J. Geophys. Res.: Solid Earth 115(B1). 
Tobin T. S., Bitz C. M. and Archer D. (2017) Modeling climatic effects of carbon dioxide emissions from Deccan Traps volcanic eruptions around the Cretaceous-Paleogene boundary. Palaeogeogr., Palaeoclimatol., Palaeoecol. 478, 139-148.

Trull T., Nadeau S., Pineau F., Polvé M. and Javoy M. (1993) CHe systematics in hotspot xenoliths: implications for mantle carbon contents and carbon recycling. Earth Planet. Sci. Lett. 118, 43-64.

Upton B. G. J. and Wadsworth W. J. (1966) The basalts of Réunion island, Indian Ocean. Bull. Volcanol. 29, 7-23.

Valer M. (2016) Caractérisation des stockages magmatiques profonds sous les volcans de La Réunion: apports de la pétrogéochimie des inclusions magmatiques $\mathrm{PhD}$ thesis. Université Clermont Auvergne, Clermont-Ferrand, France.

Valer M., Bachèlery P. and Schiano P. (2017a) The petrogenesis of plagioclase-ultraphyric basalts from $\mathrm{La}$ Réunion Island. $J$. Petrol. 58(4), 675-698.

Valer M., Schiano P. and Bachèlery P. (2017b) Geochemical characteristics of the La Réunion mantle plume source inferred from olivine-hosted melt inclusions from the adventive cones of Piton de la Fournaise volcano (La Réunion Island). Contrib. Mineral. Petrol. 172, 74.

Villeneuve N. and Bachèlery P. (2006) Revue de la typologie deséruptions au Piton de la Fournaise, processus et risques volcaniques associés. CyberGeo, 1-25.

Viti C. and Frezzotti M. L. (2000) Re-equilibration of glass and $\mathrm{CO}_{2}$ inclusions in xenolith olivine: a TEM study. Am. Mineral. 85, 1390-1396.

Vlastelic I. and Pietruszka A. J. (2016) A review of the recent geochemical evolution of Piton de la Fournaise Volcano (19272010), in Active volcanoes of the southwest Indian Ocean: Piton de la Fournaise and Karthala. In Active Volcanoes of the World (eds. P. Bachèlery, J. F. Lénat, A. Di Muro and L. Michon). Springer, Berlin.

Wallace P. J., Kamenetsky V. S. and Cervantes P. (2015) Melt Inclusion $\mathrm{CO}_{2}$ contents, pressures of olivine crystallization and the problem of shrinkage bubbles. Am. Mineral. 100(4), 787-794.

Wanamaker B. J. and Evans B. (1989) Mechanical re-equilibration of fluid inclusions in San Carlos olivine by power law creep. Contrib. Mineral. Petrol. 102, 102-111.

Wech A. G. and Thelen W. A. (2015) Linking magma transport structures at Kilauea volcano. Geophys. Res. Lett. 42, 7090-7097.

Welsch B., Famin V., Baronnet A. and Bachèlery P. (2013) Dendritic crystallization: a single process for all textures of olivine in basalts? J. Petrol. 54, 539-574.

Yamamoto J. and Burnard P. (2005) Solubility controlled noble gas fractionation during magmatic degassing: Implications for noble gas compositions of primary melts of OIB and MORB. Geochem. Cosmoch. Acta 69, 727-734.

Yamamoto J., Nishimura K., Sugimoto T., Takemura K., Takahata N. and Sano Y. (2009) Diffusive fractionation of noble gases in mantle with magma channels: origin of low $\mathrm{He} / \mathrm{Ar}$ in mantle-derived rocks. Earth Planet. Sci. Lett. 280, 167-174.

Zanon V. and Frezzotti M. L. (2013) Magma storage and ascent conditions beneath Pico and Faial islands (Azores archipelago): a study on fluid inclusions. Geochem., Geophys., Geosyst. 14, 3494-3514. 